\title{
The Rogowiec Landslide Complex (Central Sudetes, SW Poland) - a case of a collapsed mountain
}

\author{
Marek KASPRZAK ${ }^{1}$, Filip DUSZYŃSKI ${ }^{1}$, Kacper JANCEWICZ ${ }^{1}$, Aleksandra MICHNIEWICZ ${ }^{1}$, \\ Milena RÓŻYCKA ${ }^{1}$ and Piotr MIGOŃ ${ }^{1, *}$
}

1 University of Wrocław, Institute of Geography and Regional Development, pl. Uniwersytecki 1, 50-137 Wrockaw, Poland

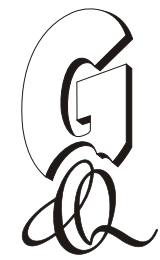

\begin{abstract}
Kasprzak, M., Duszyński, F., Jancewicz, K., Michniewicz, A., Różycka, M., Migoń, P., 2016. The Rogowiec Landslide Complex (Central Sudetes, SW Poland) - a case of a collapsed mountain. Geological Quarterly, 60 (3): 695-713, doi: 10.7306/gq.1286

The paper focuses on a large relict landslide complex in the northeastern part of the Kamienne Mts. (Sudetes, SW Poland) developed on Carboniferous and Permian volcanic and clastic sedimentary rocks. Whilst the presence of mass movements around Mt. Rogowiec has long been known, no attempts have yet been made to offer a comprehensive analysis. This study is based on recognition of geomorphic features from LiDAR-derived DTM, geomorphometric analysis, field geomorphological mapping, joint measurements at representative exposures, and electrical resistivity tomography. The total area affected by gravitational slope deformation exceeds 40 ha and consists of a few smaller units that show distinctive patterns of displacement. The eastern slopes of the Mt. Rogowiec ridge have been reshaped by large slides involving rigid blocks of trachyandesite in the upper part and deformed sedimentary successions in the middle and lower part. The centra part of the area has experienced lateral spreading which resulted in complete disintegration of the volcanic cap. Fresh-looking ridge-top trenches indicate that this process is ongoing. Subsequent movements included flows into pre-existing valleys and rock wall collapses to produce spectacular block streams. The scale and variety of deformation structures at Mt. Rogowiec make this locality unique in the Sudetes.
\end{abstract}

Key words: landslide, hillslopes, digital terrain models, LiDAR, geomorphometry, electrical resistivity tomography.

\section{INTRODUCTION}

The Sudetes - a medium-altitude (max. 1603 m a.s.I.) mountain range that straddles the border between Poland and the Czech Republic - has long been considered as an area where landslides are few and infrequent. In comparison with the Carpathians, the role of large-scale mass movements in landscape evolution was regarded as minor and subordinate to other surface processes acting during the Quaternary, such as weathering, shallow ground displacements, and fluvial erosion. Several historical events, such as the August 1598 rockslide in Bardo, were presented as geomorphic anomalies rather than significant components of the contemporary geomorphic system. Debris flows in the Karkonosze Mts. have been documented since the late 19th century (Pilous, 1977), but given their initiation above the timberline, the relevance of debris flows for hillslope behaviour in forested areas was considered limited.

This perspective changed in 1997 and 1998, when tens of shallow slips and some deep-seated landslides were generated following abnormally heavy summer rainfall (Aichler and Pecina, 1998; Czerwiński and Żurawek, 1999; Żurawek, 1999).

* Corresponding author, e-mail: piotr.migon@uwr.edu.pl

Received: July 28, 2015; accepted: February 17, 2016; first published online: March 29, 2016
Later research, focused on Permian volcanic terrain in the central part of the Sudetes (Kamienne Mts.), resulted in the recognition of more than 25 localities with slope deformation structures, including deep-seated ones (Synowiec, 2003, 2005). More recently, the inventory of landslides in the eastern part of the Kamienne Mts. alone has increased to nearly 50 , based on combined landform recognition in the field and on LiDAR-derived DTMs (Migoń et al., 2014b). The availability of high-resolution LiDAR data helped also to recognize and map landslides of different types, including deep-seated ones, in other massifs within the Sudetes such as the Stołowe Mts. (Migon and Kasprzak, 2011, 2016), Bystrzyckie Mts. (Różycka et al., 2015), and Wałbrzyskie Mts. (Migoń et al., 2015). The temporal context of their activity remains an open question, although soil development indicators suggest that some displacements may have occurred during the Holocene and in very recent times (Kacprzak et al., 2013).

Most landslides in the Sudetes are small, with areas $<10$ ha. For instance, in the eastern part of the Kamienne Mts, only 10 out of 47 mapped landslides exceed this size, although some of these are spatially associated with smaller ones to form more extensive landslide complexes, covering 40-50 ha (Migoń et al., 2016). Sliding usually occurred within the middle and lower slope sections, apparently oversteepened by basal fluvial undercutting or internal deformation of weak sedimentary strata under the weight of overlying heavy and massive volcanic rock. Upper slopes and crest lines were typically left unaffected by deformation. 


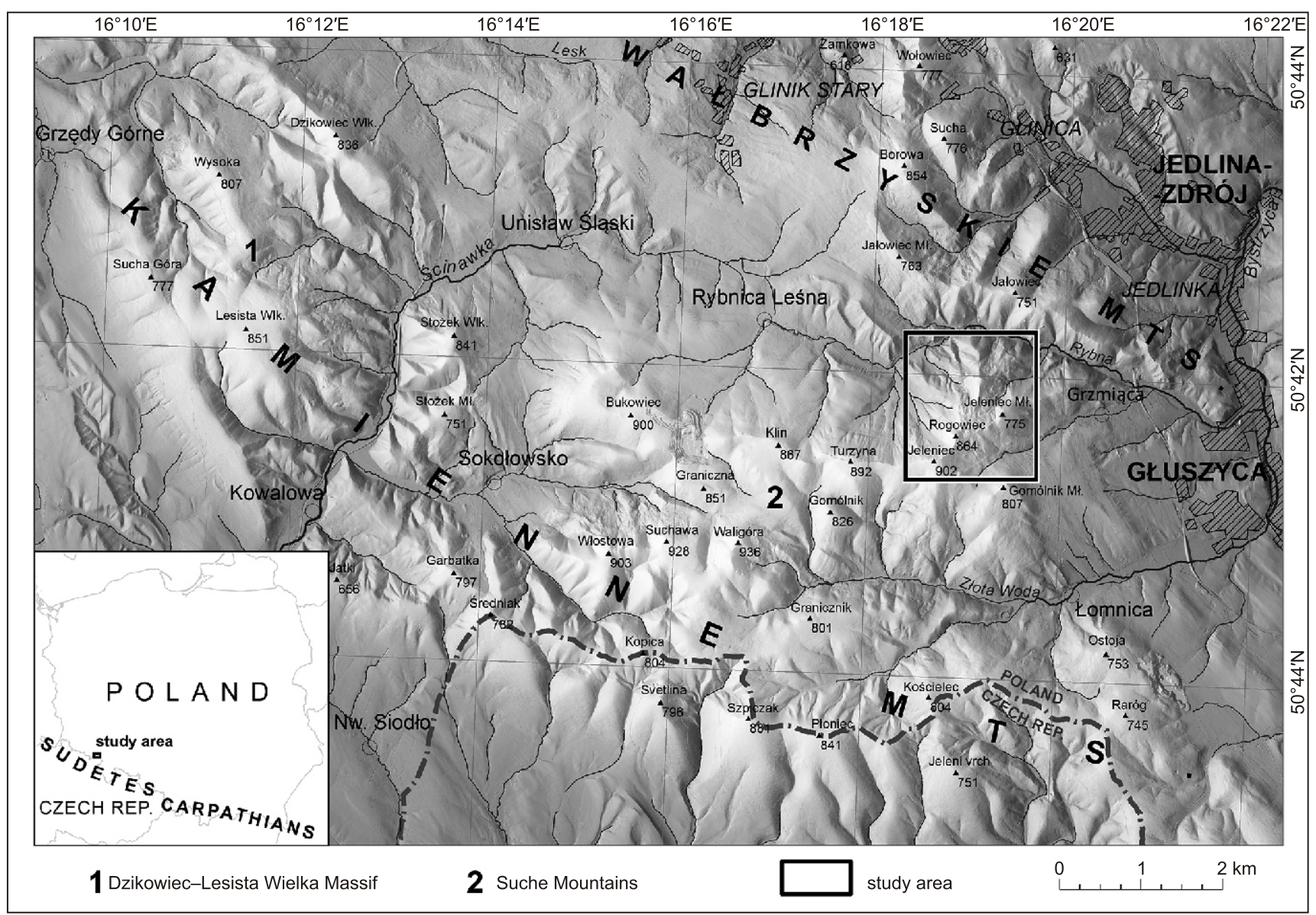

Fig. 1. Location map

The extent of the rectangle corresponds with Figure 4

In this paper the focus is on an unusual example from the Kamienne Mts., where the conical peak of Mt. Rogowiec and the adjacent part of the divide (Fig. 1) have been undermined by landslides from nearly all sides, almost as far as the crest, leading to the complete re-modelling of the axial part of the ridge. Pulinowa (1972) briefly described a landslide on the eastern slope of Mt. Rogowiec, but failed to recognize that it is part of a much wider area of gravitational deformation. Synowiec (2003) and Migoń et al. (2014b) identified further landslides in the Rogowiec massif, but did not attempt a more thorough analysis. In addition, Synowiec (2005) dated two sediment samples from two ponds within the landslide complex. Both ages are mid- to late Holocene, likely indicating reactivation of deformation. Thus, the main aims of this paper are: (1) to provide comprehensive geomorphometric and geomorphological characteristics of the Rogowiec Landslide Complex (RLC); (2) to explore the likely structural control of deformation and its internal structure using ERT profiling; (3) to offer an evolutionary model of landslide-driven evolution of the ridge. The timing of displacements is beyond the scope of this paper, although no historical record (i.e. from the last 200 years or so) of mass movements is available from the region.

\section{STUDY AREA AND STUDY SITE}

Mt. Rogowiec is located in the northeastern part of the Suche Mts., which are the eastern and the highest geographical unit of the Kamienne Mts., culminating in Mt. Waligóra
(936 m a.s.l.; Fig. 1). There are a few specific topographic features that distinguish the Suche Mts. from other ranges of the Sudetes. Relief energy is high and locally exceeds $350 \mathrm{~m}$ per $1 \mathrm{~km}^{2}$. Water divides are typically very well-pronounced, occasionally turning into narrow, rocky crest lines. Most slopes have straight longitudinal profiles, especially if underlain by one type of bedrock, whereas in certain places basal slope concavities are evident. Another characteristic feature is deep, V-shaped valleys, often lacking perennial streams. These two spatially contiguous landforms - smooth slopes with linear profiles and deeply incised valleys - are good surface manifestations of areas which were not remodelled by mass movements (Migoń et al., 2010, 2014b). By inference, more diverse slope relief has long been considered as indicative of the considerable role played by landslides in hillslope evolution (Dathe et al., 1910; Dathe and Berg, 1926; Grocholski, 1972; Synowiec, 2003; Migoń et al., 2014b).

Specific geomorphic features of the Suche Mts. are related to geological structure. The area is built of volcanic and sub-volcanic rocks (trachyandesites, rhyolites, rhyolitic tuffs), mainly of Early Permian age (Awdankiewicz, 1999), which overlie or are inserted between clastic sedimentary rocks of Late Carboniferous/Early Permian age (Bossowski and Ihnatowicz, 1994). The volcanic rocks are mechanically much stronger than the sedimentary strata (Placek, 2011) and hence, more resistant to weathering and erosion. Therefore, they tend to cap ridges and mountain peaks whereas valley bottoms and minor intermontane depressions are preferentially excavated in the sedimentary successions. Geomechanical contrasts between 
volcanic and sedimentary rocks and the consequent differential deformation have long been considered as crucial factors in the initiation and occurrence of slope movements (Grocholski, 1972; Pulinowa, 1972; Migoń et al., 2014b). Limited surface drainage in the upper and middle slopes, as well as of headwater valley reaches, reflected in the geographical name (Suche Mts. = 'Dry' Mountains), indicates the good permeability and high infiltration capacity of the jointed volcanic bedrock, despite annual precipitation of $800-1000 \mathrm{~mm}$.

The general morphology of the study site consists of a N-S trending ridge, with two distinct culminations. The southern one is Mt. Rogowiec, whereas the northern one is unnamed and assumes the shape of a pointed ridge, peaking at $776 \mathrm{~m}$ a.s.I A secondary ridge of Mt. Jeleniec Mały trends towards the ENE. Of particular significance appears to be the area between the two peaks in the main ridge, around the $786 \mathrm{~m}$ height point and east of it, where the dividing ridge transforms into highly irregular terrain (Figs. 2 and 3).

Geologically, the area around Mt. Rogowiec is complex, as shown on the 1:25,000 geological map (Bossowski et al., 1994 Fig. 4), although it is not excluded that part of this complexity may be related to slope movements unrecognized at the time of geological mapping. The main $\mathrm{N}-\mathrm{S}$ divide is underlain by trachyandesites (according to the revised terminology of the Permian volcanic rocks - see Awdankiewicz, 1999), except one minor section in the least elevated part of the divide, where sedimentary rocks are indicated. Mid- and lower slope sections are underlain by sedimentary rocks too, mapped as conglomerate-sandstone-mudstone-claystone associations. The Jeleniec Mały ridge is built of rhyolites. In addition, Bossowski et al. (1994) indicated the widespread presence of colluvial deposits, including landslide depositional areas, superimposed on bedrock geological boundaries. The area is crossed by a NNE-SSW trending fault which runs across the eastern slope of Mt. Rogowiec.

\section{DATA SOURCES AND METHODS}

The study involved four major components. First, digital elevation data allowed us to produce a high-resolution digital elevation model of the study area which was used to derive geomorphometric characteristics of the terrain and to aid landform mapping. Second, field geomorphological mapping was carried out. Third, fractures were measured at selected rock exposures in order to identify structural controls on landslide development and morphology. Fourth, electrical resistivity tomography was employed to obtain information about geological conditions at depth.

\section{LiDAR DEM}

Digital terrain model (DTM) of $1 \times 1 \mathrm{~m}$ resolution, derived from a point cloud acquired through airborne laser scanning (ALS), was the primary source of information regarding the topography of the Mt. Rogowiec area. The source dataset, provided as ASC files, was obtained from the Polish Centre of Geodetic and Cartographic Documentation. The density of the source point cloud is 4-6 points per $1 \mathrm{~m}^{2}$, the mean elevation error is $0.05-0.15 \mathrm{~m}$ and the maximum error does not exceed $0.3 \mathrm{~m}$. The mean localization error of the ALS point cloud is $<0.5 \mathrm{~m}$ (Wężyk, 2014). The final DTM, produced by removal of points reflected from terrain cover elements (vegetation, infrastructure), is a bare ground type model and offers the best approximation of elevation distribution in the study area, far exceeding the accuracy of 1:10,000 topographic maps available so far. Minor errors and inaccuracies related to the removal of small-scale topographic objects (e.g. boulders), incorrectly classified as elements of land cover during data processing (Sithole and Vosselman, 2004), cannot be excluded. Therefore, landform mapping had to be supplemented by ground

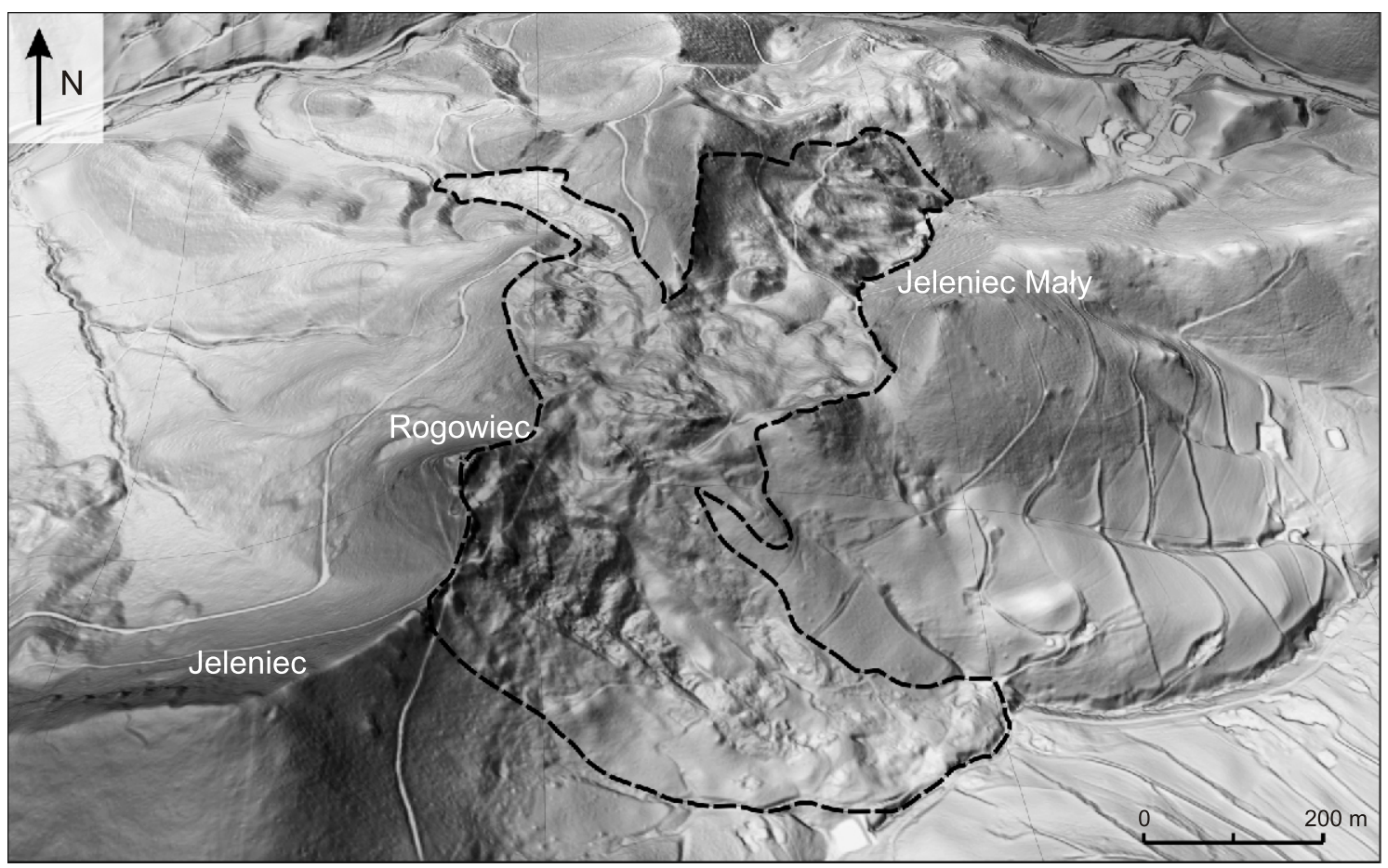

Fig. 2. LiDAR-based three-dimensional model of Mt. Rogowiec area highlights morphological contrasts between slopes affected by gravitational deformation processes (dotted line) and those unaffected 


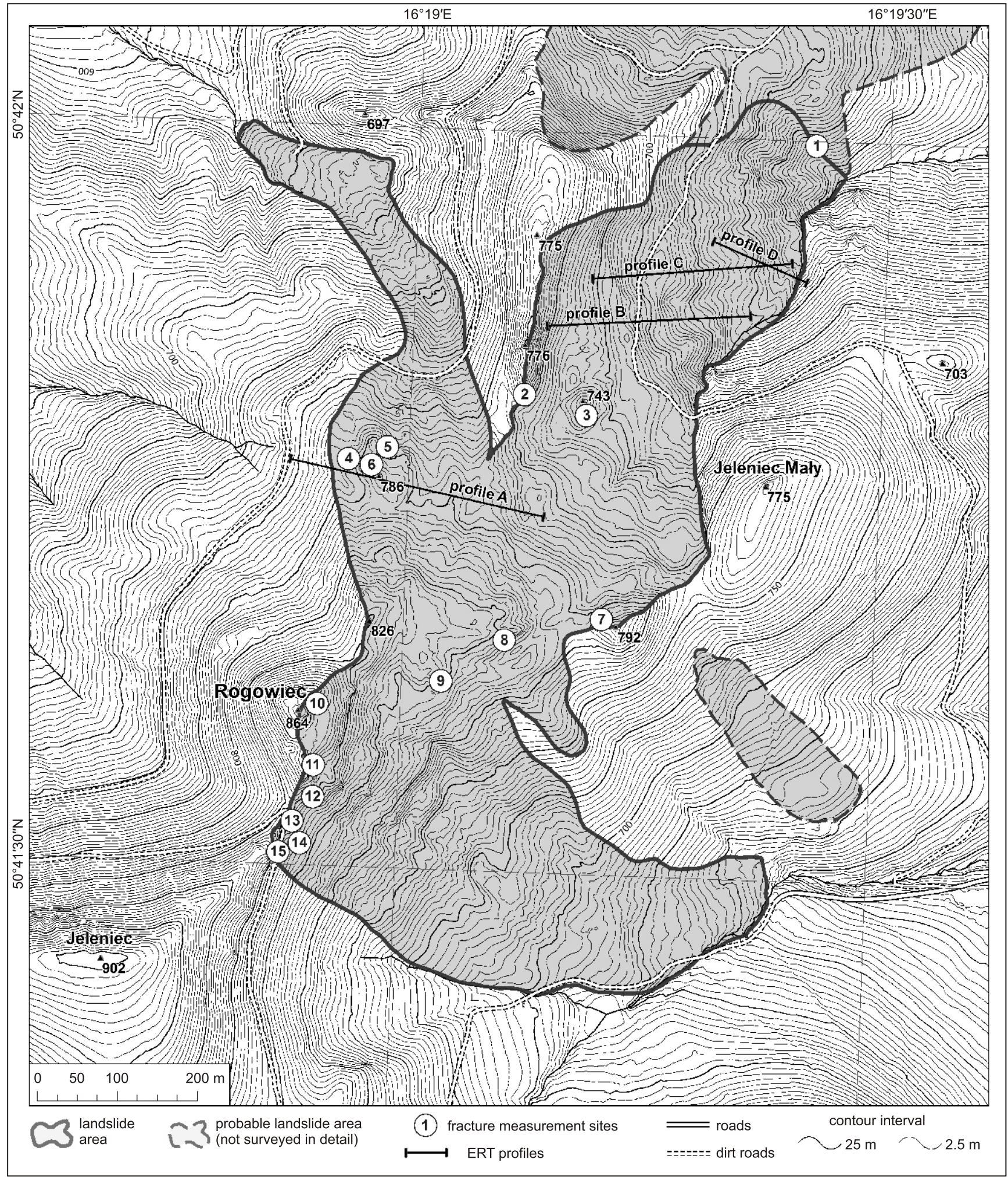

Fig. 3. Altitude relationships in the Rogowiec area and spatial limit of the Rogowiec Landslide Complex (thick solid line) 


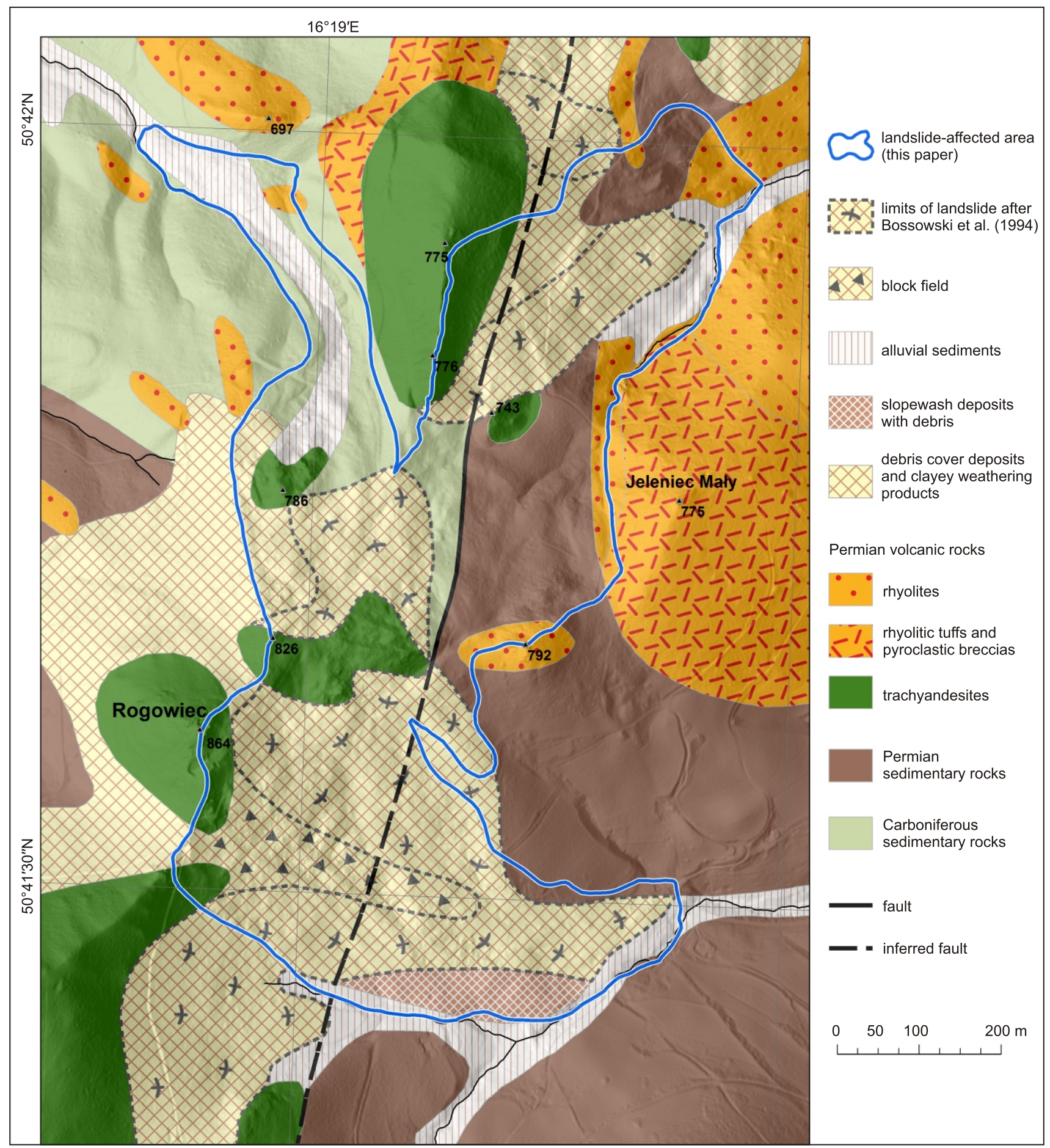

Fig. 4. Geology of Mt. Rogowiec area and its relation to the limits of the Rogowiec Landslide Complex

Simplified from Bossowski et al. (1994)

checking and field mapping. DTM analysis was carried out using GlobalMapper, SAGA GIS and Arc GIS software. Three key parameters used to characterize landforms of the study area are slope, profile curvature and the topographic wetness index (TWI). The latter is a function of slope and upstream contributing area per unit width orthogonal to the flow direction, and is used to identify hydrological flow paths (Sørensen et al., 2006) This parameter, in a SAGA GIS modified version (Olaya and Conrad, 2008), is used as a proxy to characterize surface roughness within the landslide terrain and to detect depressions lacking surface outflow.

FIELD GEOMORPHOLOGICAL MAPPING

Detailed field mapping of the entire study area was necessary because of dense, nearly continuous forest cover on the Mt. Rogowiec ridge and adjacent ridges and slopes. It focused 
on two main tasks: (1) verification of information derived from high-resolution DTM; (2) identification of minor terrain elements, not evident or completely absent on the DTM, but considered important for the recognition of landslide patterns. The latter included bedrock scarps, disintegrated bedrock exposures, boulder fields, and individual boulders dispersed across the area. The location of specific points was carried out using GPS receivers, with 3-5 m accuracy. Given the lack of well-defined boundaries of individual landslide elements, this level of accuracy was considered acceptable. Morphological features of slopes outside the RLC area were noted during the fieldwork but not indicated on the final map, the coverage of which is limited to the landslide-affected terrain. The end result is the geomorphological map of the area at 1:7,500 scale, created using ArcGIS software. The key to the map includes nearly 30 symbols for point, linear and surface features.

\section{JOINT MEASUREMENTS}

The purpose of carrying out structural measurements of discontinuities within the RLC was twofold. First, we intended to identify discontinuities along which detachments have taken place and how they relate to the jointing pattern of the rock mass as a whole. Second, it was assumed that results of measurements at apparently displaced bedrock blocks would help us to recognize the pattern and sense of movement. Consequently, among 15 individual sites selected for measurements (see Fig. 3 for location) two groups may be distinguished.

The first group includes 6 sites within head scarps (labelled no. $2,7,10,11,13,15)$, with jointed bedrock in situ exposed over distances of tens of metres. These rock exposures were generally easily accessible, allowing us to collect sufficiently large, and representative data (around 50 readings at each site), with the exception of site no. 7 , where the rocky head scarp is less distinct and clear primary fractures were scarce. The second group consists of 9 blocks that have moved from their original position. In three cases, the displaced blocks are only 10-30 m apart from head scarp faces (no. 3, 12, 14) and hence, the results of measurements may be compared with those obtained from in situ rock exposures in their close vicinity. The remaining blocks are located either far away from detachment zones (no. 1) or they cannot be traced to any in situ rock exposure due to their water divide setting (no. 4-6, 8-9). In each of these cases, the limited size of rock blocks and significant degree of weathering precluded the collection of large joint data sets, and only $10-30$ readings were taken at each location.

Measurements were carried out on exposures of volcanic rocks only. Nowhere within the RLC are sedimentary rocks exposed in such a manner that would allow collection of representative data.

The dataset, collected in the field using a geological compass, was processed in the Stereonet 9 programme (Allmendinger et al., 2012; Cardozo and Allmendinger, 2013; Allmendinger, 2013). The software allowed us to plot the results as stereonets of dip angle and dip direction.

\section{ELECTRICAL RESISTIVITY SURVEYS}

While developing the model of rock mass deformation within Mt. Rogowiec and adjacent ridges and slopes, an understanding of geological conditions at depth was crucial. Existing geological maps were somewhat vague in this respect (Bossowski et al., 1994). Therefore, electrical resistivity tomography (ERT) was used, being a method particularly suitable for the recognition of geological relationships at shallow depths
(Samouëlian et al., 2005; Kneisel, 2006; Schrott and Sass, 2008; Loke et al., 2013). There are many papers documenting the usefulness of ERT surveys in landslide research (e.g., Pánek et al., 2008, 2011; Carpentier et al., 2012; Perrone et al., 2014), including the Kamienne Mts. where both deep-seated (Migoń et al., 2010) and shallow, flow-like slope movements (Migoń et al., 2014a) have been detected.

The essence of electrical resistivity tomography are resistivity measurements $(R)$ carried out in multiple four-electrode recording arrays. In each array the electric current $(I)$ is transmitted to the ground through two electrodes $\left(C_{1}, C_{2}\right)$, whereas voltage - difference of potentials $(V)$ - is measured by the second pair of electrode $\left(P_{1}, P_{2}\right)$. Since the rock mass is not uniform, the measured resistivity expressed as the voltage/current ratio and modified by the $k$ coefficient dependent on the selected electrode array and electrode spacing, is in fact an apparent resistivity. While moving the measurement array along a profile and increasing electrode spacing, one can obtain multiple measurement points in separate horizons.

Resistivity data were obtained using an ARES (GF Instruments, Brno, Czech Republic) device. The Wenner-Schlumberger electrode array (Loke, 2000; Reynolds, 2011) was chosen in order to get sufficient vertical resolution and considerable depth penetration. Electrode spacing was set for $5 \mathrm{~m}$. Electrical resistivity values, expressed in $\Omega \mathrm{m}$, were subject to standard geophysical interpretation (inversion) using RES2DINV software (Geotomo, Malaysia). The procedure involves default smoothness-constrained inversion formulation (last squares inversion). Logarithmic scale was used for graphic visualization of inverse results. In order to facilitate comparative analysis of all profiles measured, a uniform colour scale was adopted.

Four ERT profiles were measured, all north of the main peak of Mt. Rogowiec (see Fig. 3 for location). Profile A is perpendicular to the water divide and was located in the area where the topographic expression of the divide is particularly weak. Profiles $B$ and $C$ run across the eastern slope of a distinct ridge farther north, the surface morphology of which suggests deep-seated deformation affecting the volcanic-sedimentary succession. Profile D was located in the toe of the above-mentioned slope, across a distinct ridge marking the east lateral boundary of the landslide-affected terrain.

\section{GEOMORPHOMETRIC CHARACTERISTICS}

For the geomorphometric analysis of the Rogowiec Landslide Complex, maps of primary and secondary parameters such as slope, profile curvature and topographic wetness index (TWI) were generated from a re-interpolated DTM of $3 \times 3 \mathrm{~m}$ resolution (Fig. 5). The complex morphology of the landslide terrain is evident, especially if considered in a wider perspective of the adjacent slopes with smooth longitudinal profiles. Based mainly on the map of slope inclination and direct expert examination of terrain model, an attempt was made to divide the RLC into relatively homogeneous units (Fig. 5). Altogether, within the total of 40 ha, nine such areas have been distinguished and these vary in size from c. 2 ha (no. 2) to c. 8 ha (no. 5). For each unit selected morphometric characteristics were calculated (Table 1).

Mean slope is a variable that differentiates the RLC area into two groups. One consists of four units which are less inclined, $<20^{\circ}$ on average (no. $4,5,6,7$ ). Three of these are located in the lower slope sections, towards the valley floors or even within valley floors (no. 7), but the fourth one includes the divide zone (no. 5). Among the four units are three with the largest extent (no. $4,5,6$ ) and these have the lowest mean slope values, ranging from 15.2 to $18.1^{\circ}$. Other morphometric charac- 

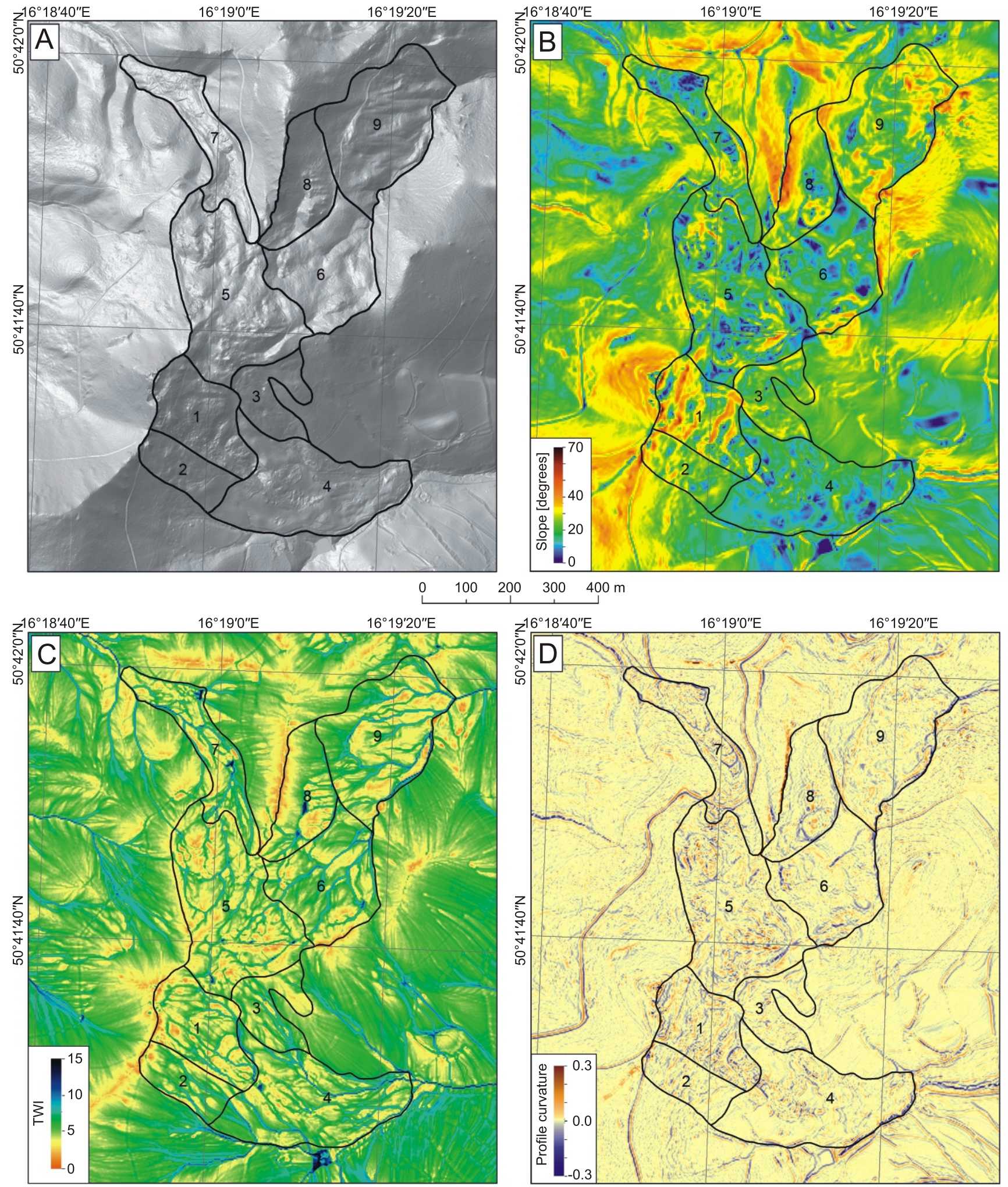

Fig. 5. Geomorphometric features of the Rogowiec Landslide Complex

A - shaded relief, B - slope map, C - topographic wetness index, D - profile curvature; 1-9 - terrain units interpreted from DTM 
Table 1

Selected geomorphometric parameters of terrain units within the Rogowiec Landslide Complex (numbering of units consistent with Fig. 5D)

\begin{tabular}{|l|c|c|c|c|c|c|c|}
\hline Unit & $\begin{array}{c}\text { Area } \\
{[\mathrm{ha}]}\end{array}$ & $\begin{array}{c}\mathrm{H}_{\min } \\
{[\mathrm{m} \text { a.s.I.] }}\end{array}$ & $\begin{array}{c}\mathrm{H}_{\max } \\
{[\mathrm{m} \text { a.s.I. }]}\end{array}$ & $\begin{array}{c}\text { Mean } \\
\left.\text { slope }{ }^{\circ}\right]\end{array}$ & $\begin{array}{c}\text { TWI } \\
\text { range }\end{array}$ & $\begin{array}{c}\text { Profile } \\
\text { curvature } \\
\text { range }\end{array}$ & $\begin{array}{c}\text { Aspect } \kappa \\
\text { (kappa) }\end{array}$ \\
\hline 1 & 3.74 & 720.2 & 863.3 & 27.2 & 15.8 & 0.50 & 3.79 \\
\hline 2 & 2.02 & 729.0 & 831.3 & 24.5 & 8.7 & 0.31 & 10.10 \\
\hline 3 & 2.22 & 713.6 & 794.5 & 22.7 & 9.0 & 0.46 & 5.36 \\
\hline 4 & 6.97 & 637.7 & 760.2 & 15.2 & 12.1 & 0.49 & 2.77 \\
\hline 5 & 8.18 & 735.7 & 826.3 & 18.1 & 13.4 & 0.68 & 1.05 \\
\hline 6 & 5.05 & 704.2 & 790.4 & 18.0 & 12.7 & 0.64 & 2.38 \\
\hline 7 & 3.60 & 622.8 & 767.8 & 18.8 & 15.0 & 0.61 & 1.77 \\
\hline 8 & 3.09 & 716.6 & 773.6 & 25.9 & 13.2 & 0.35 & 2.63 \\
\hline 9 & 6.76 & 590.5 & 741.8 & 25.8 & 12.9 & 0.46 & 3.05 \\
\hline
\end{tabular}

teristics of the zones no. 5, 6 and 7 also assume similar values. This is the case of profile curvature range and von Mises kappa coefficient - a measure of concentration (reciprocal measure of dispersion) applied in statistics of circular data, whose low values indicate high variation of aspect within a given area (Fisher, 1995). The lowest value of this coefficient and hence, the most diverse topography, typifies the divide zone no. 5.

The other five units, generally encompassing upper slope sections (with the exception of unit no. 9), are markedly steeper $\left(22.7-27.2^{\circ}\right)$. The highest mean slope value of $27.2^{\circ}$ typifies units no. 1, with distinct stepped morphology consisting of steep slope sections with inclinations up to $65^{\circ}$, alternating with less inclined sections. This zone is also characterized by the highest value of TWI range (15.8), which may be used to approximate surface roughness within the landslide zone. By contrast, the lowest values of this parameter - corresponding with less diverse morphology - characterize the two smallest units no. 2 and 3, the TWI range values of which are 8.7 and 9.0, respectively. These two are also characterized by the highest values of the von Mises kappa coefficient, which means a more homogeneous aspect within grids. It needs to be emphasized that in general, TWI range values on the slopes beyond the RLC are lower, indicating less diverse surface morphology.

Based on a $1 \times 1 \mathrm{~m}$ resolution DTM, ten closely spaced (100 m apart) topographic profiles across Mt. Rogowiec and the adjacent part of the divide, each nearly $870 \mathrm{~m}$ long, were prepared (Fig. 6). Their purpose was to highlight differences in the morphology of the RLC along its axial part. While the ridge shows as a distinct relief feature on the profiles $\mathrm{A}, \mathrm{B}, \mathrm{H}, \mathrm{I}$ and $\mathrm{J}$, its distinctiveness diminishes towards the central part of the RLC (profiles $C$ and $G$ ) and then disappears (profiles D-F). Here, the divide zone can be described as an area of rough morphology with a series of hills and hollows visible on zoom-in views of D-F profiles. These secondary landforms combine to form relief with local altitude differences of up to $10 \mathrm{~m}$. Furthermore, topographic profiles located beyond the central part of the RLC indicate symmetry or asymmetry of the divides. Whereas profiles $\mathrm{A}$ and $\mathrm{J}$ are symmetrical, the others are not, and show smooth slopes with uniform inclination on one side and more complex longitudinal profiles on the opposite one. This situation is particularly evident in profile $G$ and zoom-in view of profile $\mathrm{H}$, where stepped topography of the SE-facing slope is clear. Altogether, both geomorphometric parameters and closely-spaced topographic profiles indicate considerable morphological complexity of the RLC.

\section{LANDFORM INVENTORY}

Geomorphological field mapping confirmed the boundaries and general division of the Rogowiec Landslide Complex area in several distinctive units, inferred earlier from DTM analysis (Fig. 7). It also revealed the highly diverse topography of the RLC and variable density of boulder cover throughout the area. Landform inventory is consistent with landslide morphology as suggested in previous work (Pulinowa, 1972; Bossowski et al., 1994; Synowiec, 2003) and hence, certain symbols on the map are explained as elements of landslides, for example head scarps or landslide toes. Spatial relationships between different terrain units distinguished through model and geomorphometric analysis, combined with field landform mapping, allowed us to join some of these units together, to form sub-areas of likely similar history and style of displacement. Thus, four sub-areas are distinguished within the RLC, named as southeastern, northeastern, northwestern and central. They are equivalents of units $1-2$ and 4 (southeastern), 7 (northwestern), 6-8 and 9 (northeastern), and 5 (central), identified on DTM, respectively.

The southeastern and northeastern parts are generally similar to each other in that they both consist of head scarps in the upper parts, series of benches and steps below, diverse and irregular topography in mid to lower slope sections, and terminate in distinct convex toes in the valley bottoms. However, there are also differences between them. In the southeastern part the head scarp is distinctive along nearly its entire length, except the northernmost section. Long sections are vertical walls of trachyandesite, up to $50 \mathrm{~m}$ long and $15 \mathrm{~m}$ high, partly buried by blocky talus. In the immediate front of the free faces of the head scarp, densely jointed and broken rock masses occur in a number of places. Among them, Skalna Brama (Rock Gate) - a $25 \mathrm{~m}$ long defile between the head wall and the isolated block - is the most distinctive landform (joint measurement sites no. 13 and 14). The upper slope shows hummocky relief with superimposed trachyandesite boulders of various dimensions, up to 8-10 m. Within the southern part discontinuous narrow benches and steps can be distinguished, whereas in the northern part a closed depression with a pond and boggy ground occurs. Hummocky terrain extends downslope in two strips, separated by less irregular slope topography. The most impressive feature of this part of the RLC is an elongated blocky accumulation, c. $250 \mathrm{~m}$ long and up to $80 \mathrm{~m}$ wide, extending from the rocky head scarp to the middle slope. It is composed of huge angular blocks, some as long as $10 \mathrm{~m}$, chaotically lying 

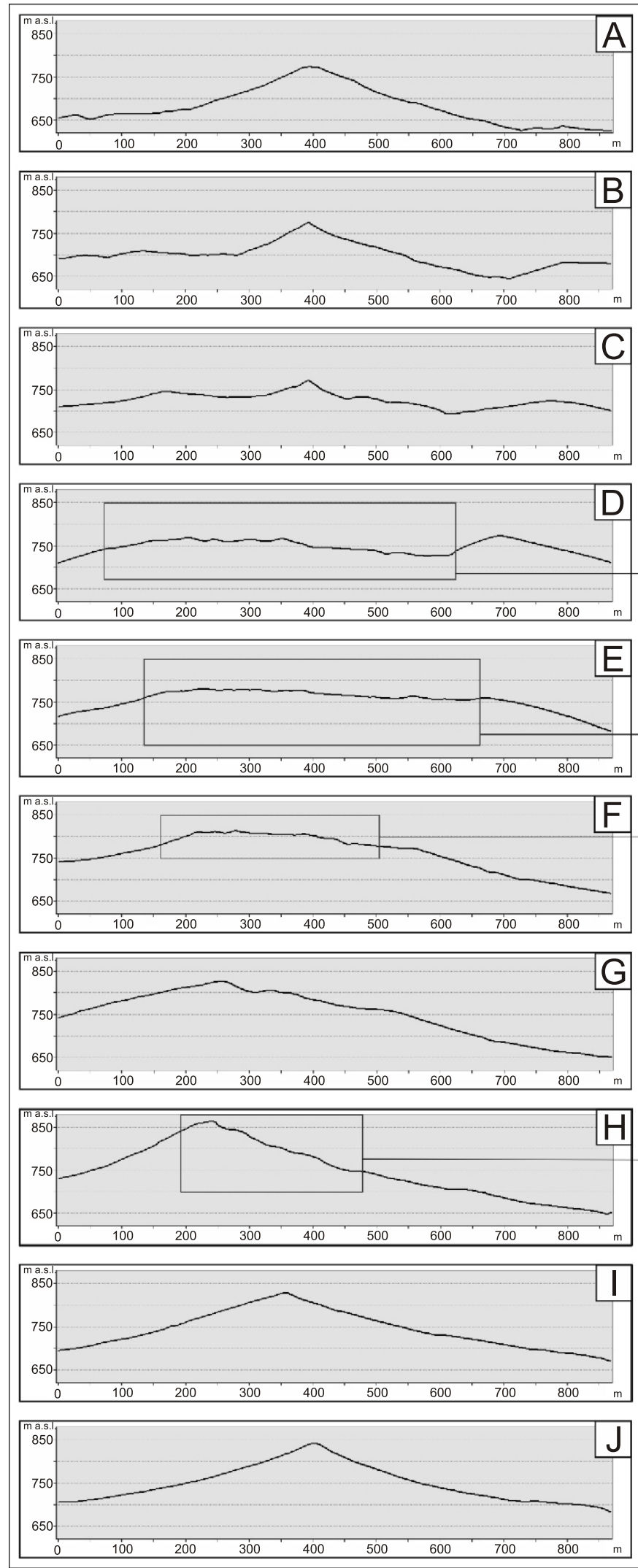
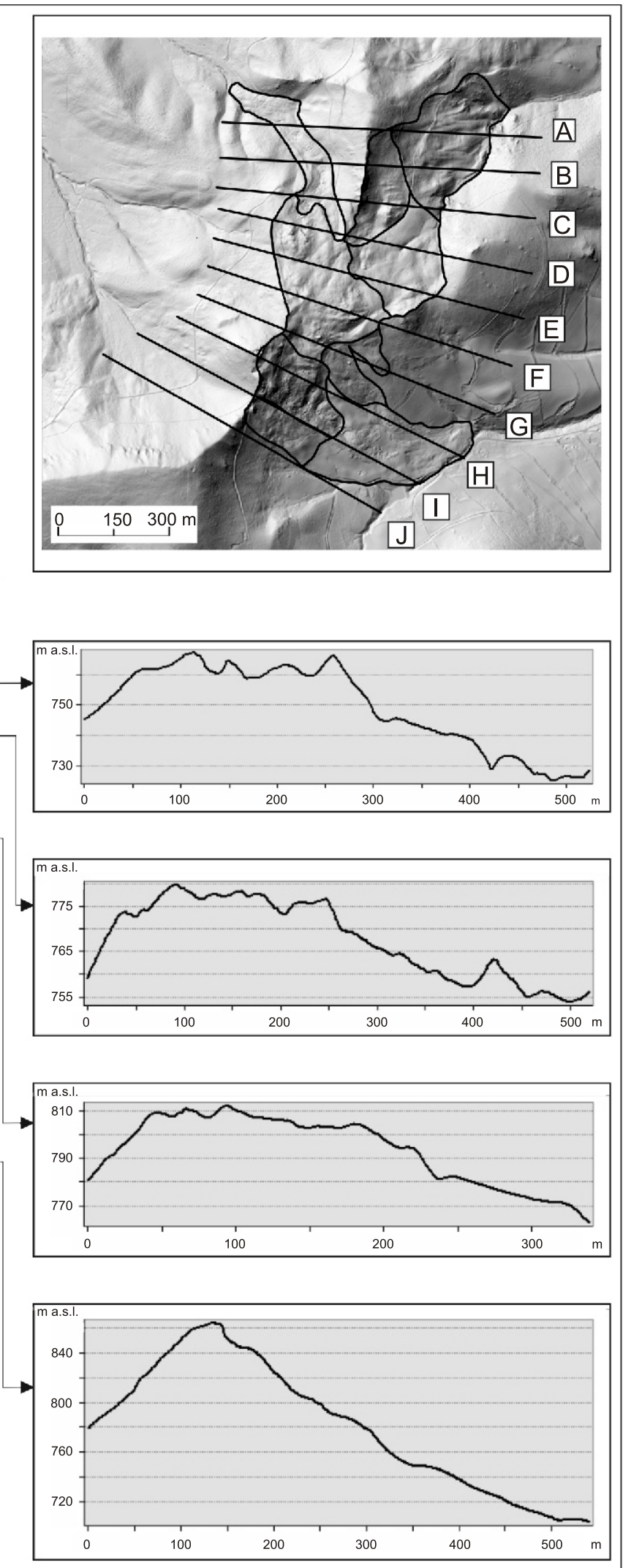

Fig. 6. Closely-spaced topographic profiles of the Rogowiec ridge 


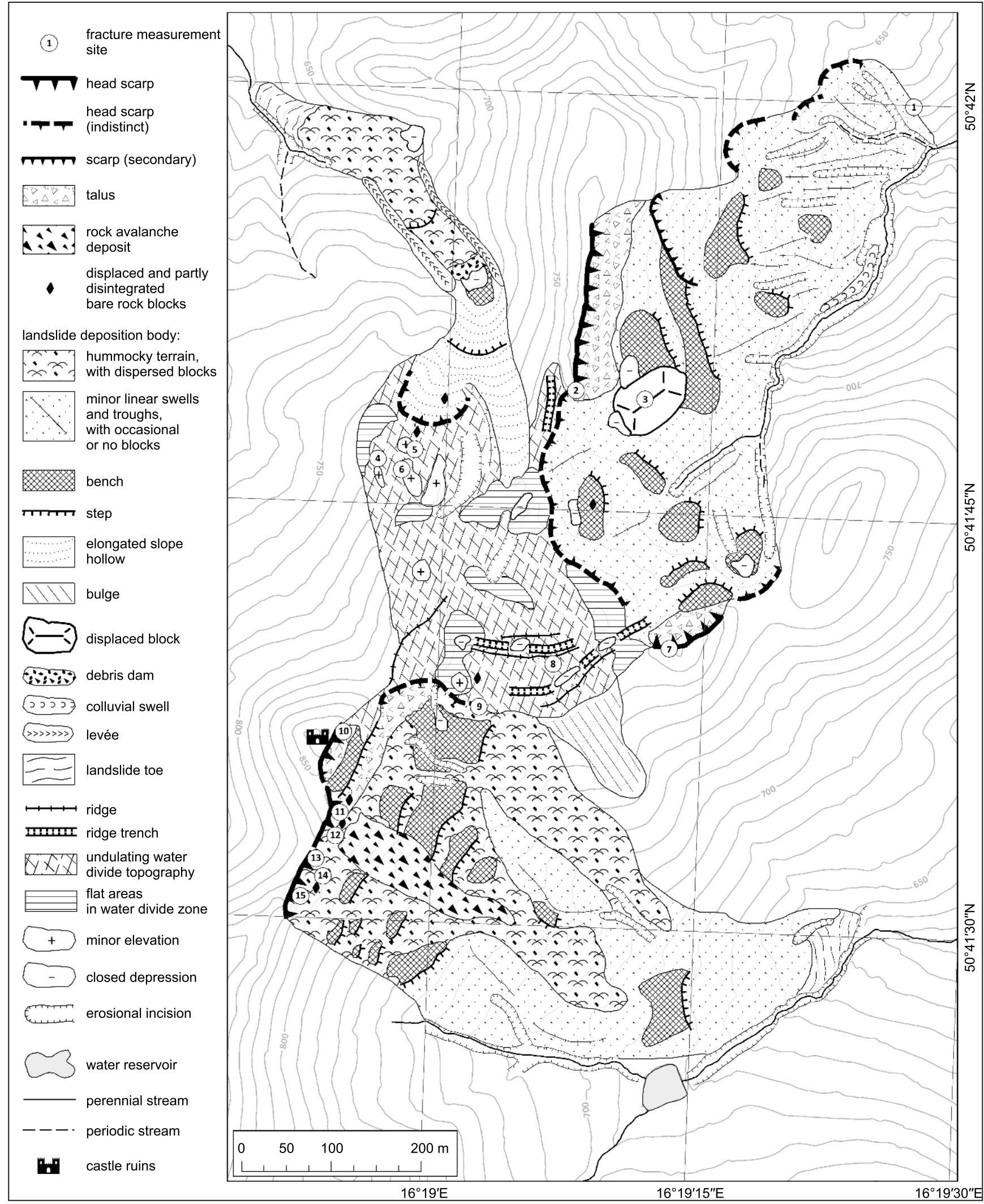

Fig. 7. Geomorphological map of the Rogowiec Landslide Complex 
upon one another, with numerous deep clefts and shafts in between. The distal part has smooth, wavy surface topography and the boulder cover is largely missing.

In the northeastern sub-area the head scarp is distinctive in the central section, where it undercuts the $\mathrm{N}-\mathrm{S}$ trending trachyandesite ridge. Here, bedrock is exposed along nearly $200 \mathrm{~m}$ and the foot of the scarp is covered by talus. A similar, but only $100 \mathrm{~m}$ long section occurs in the south and has a W-E orientation. Otherwise, the bounding scarp is much less distinct and expressed as a steeper slope section, without bedrock exposures or superimposed talus. In the northernmost part the scarp consists of a few arcuate sections. A distinctive element of the upper slope is an isolated trachyandesite hillock, $15 \mathrm{~m}$ high and $80 \mathrm{~m}$ long. Next to it two closed hollows are present, with the southern one hosting a shallow pond, largely filled by sediment. Further down an irregular pattern of benches and steps may be distinguished which then grades into a series of convex swells and intervening troughs, parallel to the slope. No boulder cover is present in this section. This irregular slope topography terminates against the opposite slope of the valley, leaving only a narrow space for the stream.

The northwestern part of the RLC is a bipartite unit, $550 \mathrm{~m}$ long in total, spatially associated with a first-order valley. Its upper part consists of two slope hollows, one semi-circular and one elongated, which converge downslope. The former is bound by a rock amphitheatre and is filled by irregular blocky talus. At the altitude of c. $700 \mathrm{~m}$ a.s.I. the zone of deposition within the valley begins. It starts with a debris ridge which dams the valley to create a shallow pond, and is followed by hummocky terrain with dispersed block cover. Most boulders are 1-2 m long but occasional monoliths up to $5 \mathrm{~m}$ long occur too. In the most distant toe part boulder cover is absent. No surface drainage occurs in this part of the valley. A notable feature is a pair of ridges on both sides of the middle section of the hummocky valley fill, each c. $150 \mathrm{~m}$ long.

The central part of the area is characterized by undulating topography, with shallow hollows, minor flats, and intervening convexities of various extent, crowned with either larger jointed rock masses, some as much as $10 \mathrm{~m}$ high, or dispersed boulders. In the southeastern part of this unit a distinctive series of trenches and bedrock ridges occur, elongated along the axis of the secondary ridge that connect the peak of Mt. Rogowiec with Mt. Jeleniec Mały. A rather indistinct, twin slope bulge south of the ridge-top trench corresponds with the unit 3 identified from DTM.

\section{JOINT PATTERNS}

\section{LANDSLIDE HEAD SCARPS}

Most fracture measurements were carried out within the $\mathrm{N}-\mathrm{S}$ trending head scarps in the trachyandesites, on the east-facing slopes of Mt. Rogowiec and the unnamed ridge farther to the north. Two sites - no. 10 and 15 - are exposed rock head scarps with no displaced blocks in their close vicinity. At site no. 10, immediately below the peak of Mt. Rogowiec (Fig. 8), dominant joint sets strike NW-SE and SW-NE, dipping towards the NE, SE and NW, respectively. The latter two dip very steeply, at angles higher than $80^{\circ}$. The NW-SE joint set, represented by c. $12 \%$ of measured fractures, dips more gently towards the $\mathrm{NE}$, at angles between $60^{\circ}$ and $80^{\circ}$. Joints dipping in the $\mathrm{E}, \mathrm{S}$ and $\mathrm{SW}$ directions are represented by a smaller number of measurements. Their dip angle is usually $>60^{\circ}$, yet in a few cases shallow dips of approximately $30^{\circ}$ were measured. The joint pattern at site no. 15 is even more complex and four
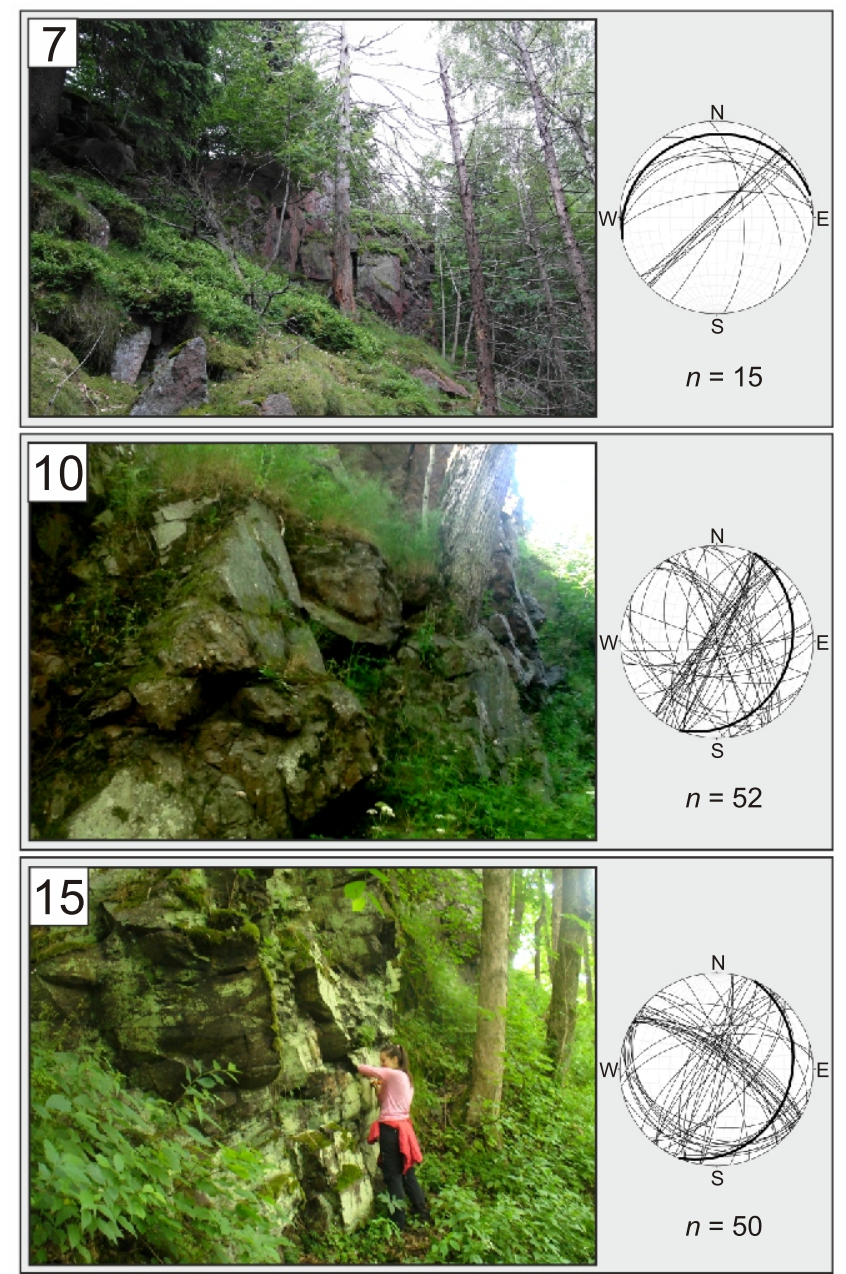

Fig. 8. Joint patterns at in situ exposures of rhyolites (no. 7) trachyandesites (no. 10, 15)

Thick solid lines show approximate inclination and direction of inclination of slope plane; numbering of measurement sites as in Figure 3

major joint sets may be distinguished, nearly perpendicular to each other. Dominant dip directions largely match those at site no. 10 and are NE (c. $34 \%$ of all measurements), SE, SW and NW. Likewise, their dip is high, typically at angles $>60^{\circ}$. The only joints dipping at angles $<30^{\circ}$ are those dipping towards the SW. At site no. 10 there is clear correspondence between the SW-NE strike of the dominant joint set and the orientation of the rock scarp. NW-dipping discontinuities control the general geometry of the scarp, whereas fractures dipping in the opposite direction are responsible for minor overhangs. Likewise, at site no. 15 the general orientation of the scarp follows the SW-NE striking joints, whereas the frequent NE-dipping joints striking NW-SE account for the jagged outline of the scarp.

The joint pattern at site no. 13 is broadly consistent with those at sites no. 10 and 15, with the prominence of steep, nearly vertical NE, E, W and NW dips. However, much gentler and nearly horizontal dips were also found among the two latter sets. Very steep dips to the east are also common at site no. 11. The second group of joints is represented by those dipping to $\mathrm{W}$ and NW, with the former being particularly steep, often at angles $>80^{\circ}$. In both cases the direction of head walls follows the $\mathrm{N}-\mathrm{S}$ strike of dominant east-dipping joints, with the remaining sets being responsible for minor irregularities of the rock sur- 

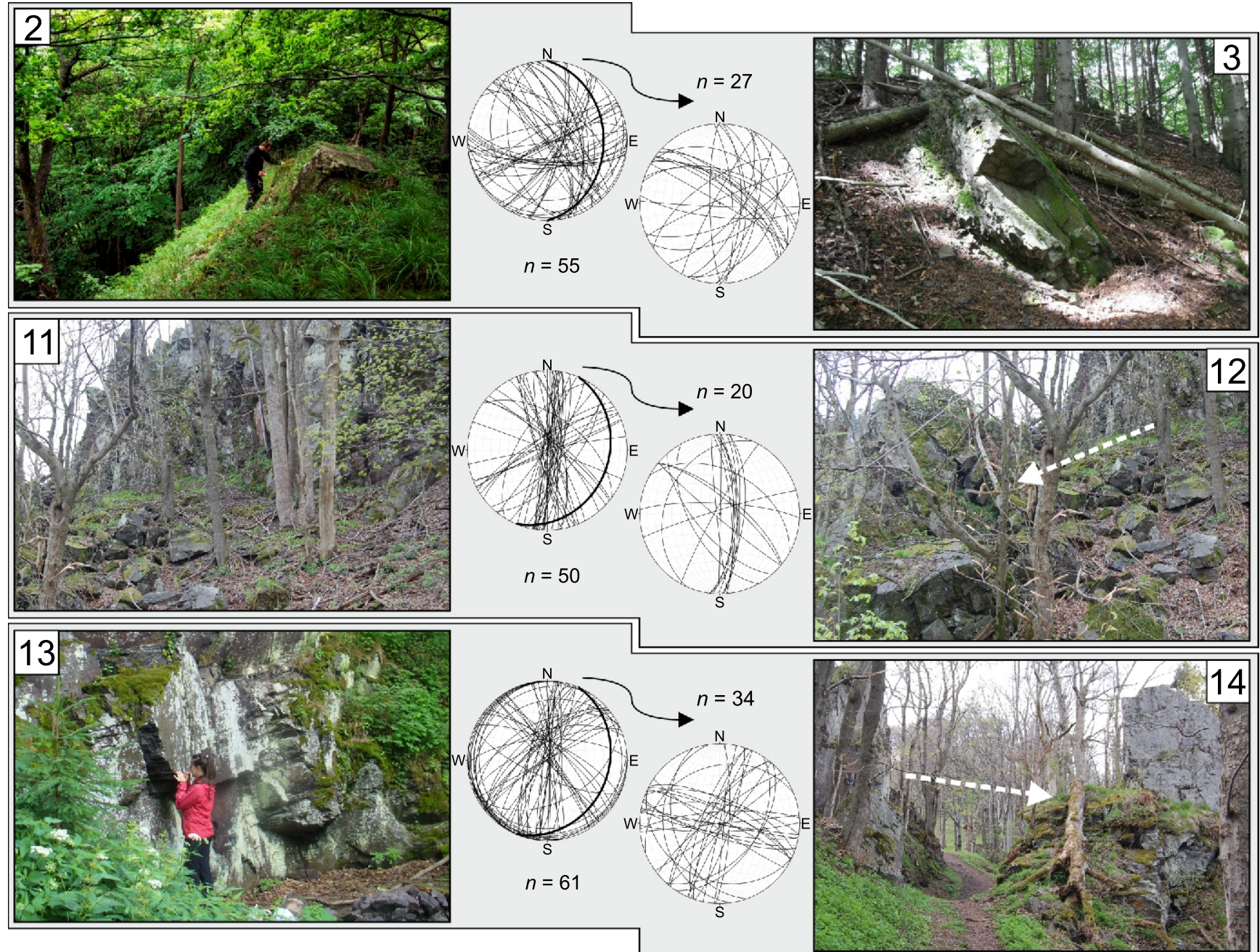

Fig. 9. Joint patterns at in situ exposures of trachyandesites and displaced blocks in their vicinity

Thick solid lines show approximate inclination and direction of inclination of slope plane; numbering of measurement sites as in Figure 3

faces. At both sites displaced blocks are located close to the head walls and these provide further insight into the nature of displacements (Fig. 9). Joint orientation data from site no. 12, located in front of the head scarp location no. 11, shows a similar general pattern, but a lower angle of dip for E-dipping joints, indicative of slight forward rotation of the detached block. By contrast, the joint pattern from the outer block at Skalna Brama (no. 14) poorly matches the pattern from the in situ exposure on the upslope side (no. 13), although horizontal clockwise rotation by c. $40^{\circ}$ may be hypothesized.

Sites no. 2 and 3 are located within the northeastern part of the RLC, where a prominent $\mathrm{N}-\mathrm{S}$ scarp cuts the ridge and a large displaced block occurs next to its south-eastern end. A variety of joint sets were found in the head scarp, most of them (ca. $80 \%$ of all) dipping steeply, at angles $>70^{\circ}$, in the ENE, ESE to SE, and $S$ directions. The extension and zig-zag detailed morphology of the rock wall are generally controlled by the strike of these generally east-dipping joint sets. In addition, joints dipping at angles $<20^{\circ}$ have been found among the NW-SE oriented fractures. Within the displaced block most joints dip to the $E$ and $N E$, with evident dominance of the latter $(>30 \%)$. The angle of dip tends to be lower than within the head scarp. Only $18.5 \%$ of joints measured in the displaced block are characterized by steep $\left(>80^{\circ}\right)$ dips. The majority dip at angles $<70^{\circ}$. Discontinuities dipping towards the $W$ are infrequent.

Site no. 7, the only one in the rhyolites, is a scarp of W-E trend facing north. The rock exposures are moderately low (3-4 m high) and massive, not allowing collection of a large number of individual measurements. The majority of joints dip towards the $\mathrm{N}$ and NW. In the former, dips vary widely, between $28^{\circ}$ and $69^{\circ}$, whereas the other set dips almost vertically. The strike of the $\mathrm{N}$-dipping joints is nearly parallel to the strike of the head scarp.

\section{DISPLACED AND DISINTEGRATED TRACHYANDESITE BLOCKS}

At six localities, displaced blocks detached from in situ exposures were large enough to allow systematic joint data collection. Blocks numbered as no. 4, 5, 6 are broken trachyandesite masses, up to $10 \mathrm{~m}$ high (Fig. 10), standing amidst the hill-and-hollow landscape in the central part of the RLC. Each of these shows a specific jointing pattern, unlike jointing patterns measured within in situ rock walls in the vicinity which were generally similar to one another. Although nearly vertical discontinuities can be identified, they do not dominate to such an extent as 

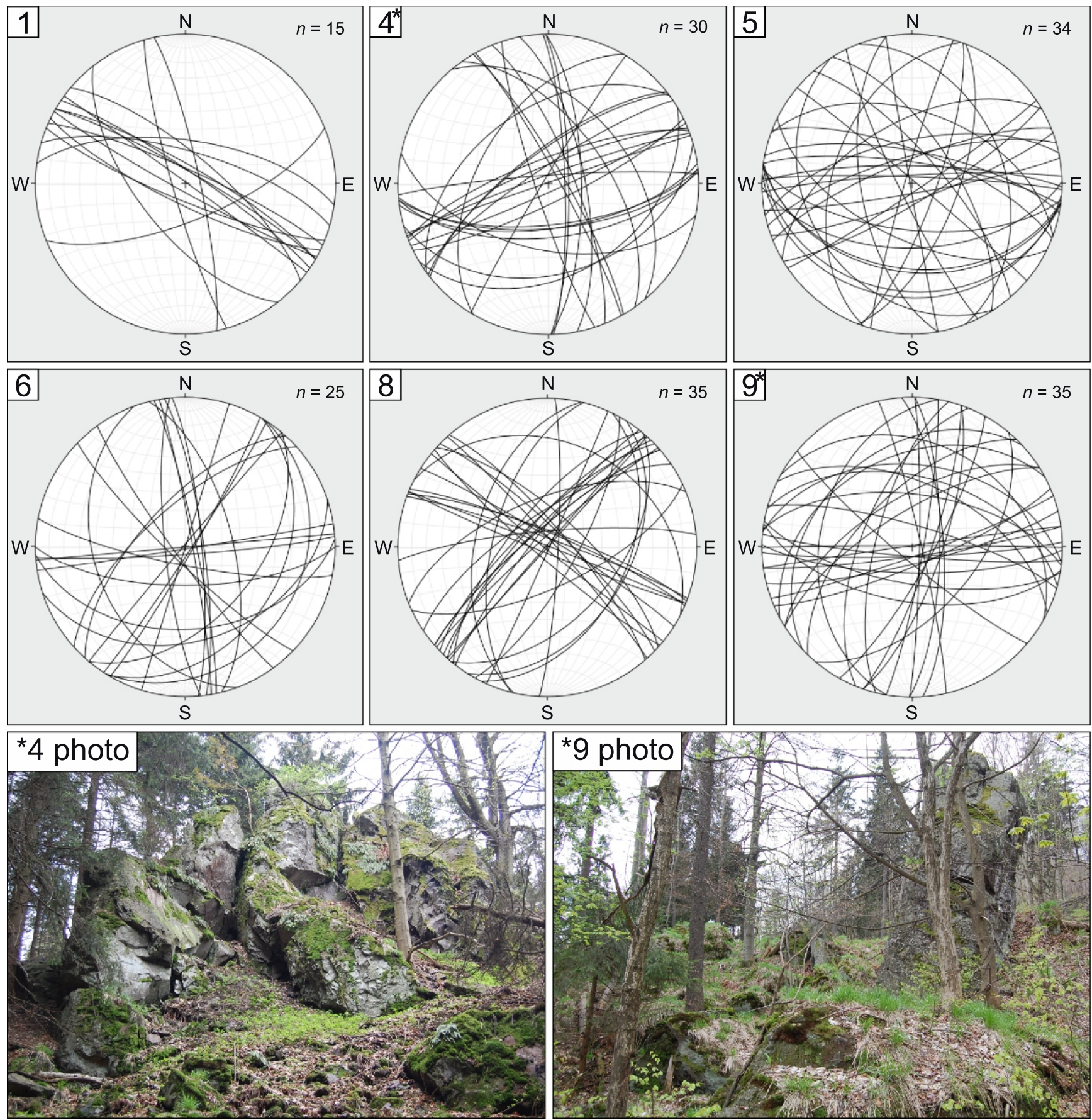

Fig. 10. Joint patterns at displaced and disintegrated blocks of trachyandesite

Numbering of measurement sites as in Figure 3

on bedrock exposures. In addition, less inclined joint planes, mostly S-dipping, are present. Block no. 5 does not show any preferred jointing pattern. A similar, apparently chaotic pattern typifies block no. 9 which appears as a solitary rock tower rising above a local flat in the southern part of the hill-and-hollow landscape. More order can be seen on block no. 8, located further east. Here NE- and NW-trending joints, dipping to SE and NE respectively, are consistent with the zig-zag geometry of a ridge-top trench situated nearby. Block no. 1 is located in the lower part of the uneven terrain in the north-east part of the RLC, far from any exposures, and is characterized by the presence of two NW-trending sets steeply dipping in opposite directions.

\section{RESULTS OF ERT MEASUREMENTS}

Results of electrical resistivity tomography allowed us to identify geological conditions at depth and to constrain conceptual models of landslide deformation at Mt. Rogowiec and adjacent ridges. However, interpretation of inversion results (Figs. 11 and 12) requires commentary on the geoelectrical properties of the bedrock. Numerical values of resistivity reflect not only bedrock lithology, but the entire set of physico-chemical properties, including texture, fracturing and fissility, as well as the presence of groundwater and its mineralisation. Furthermore, images such as those shown on Figure 12 are products 


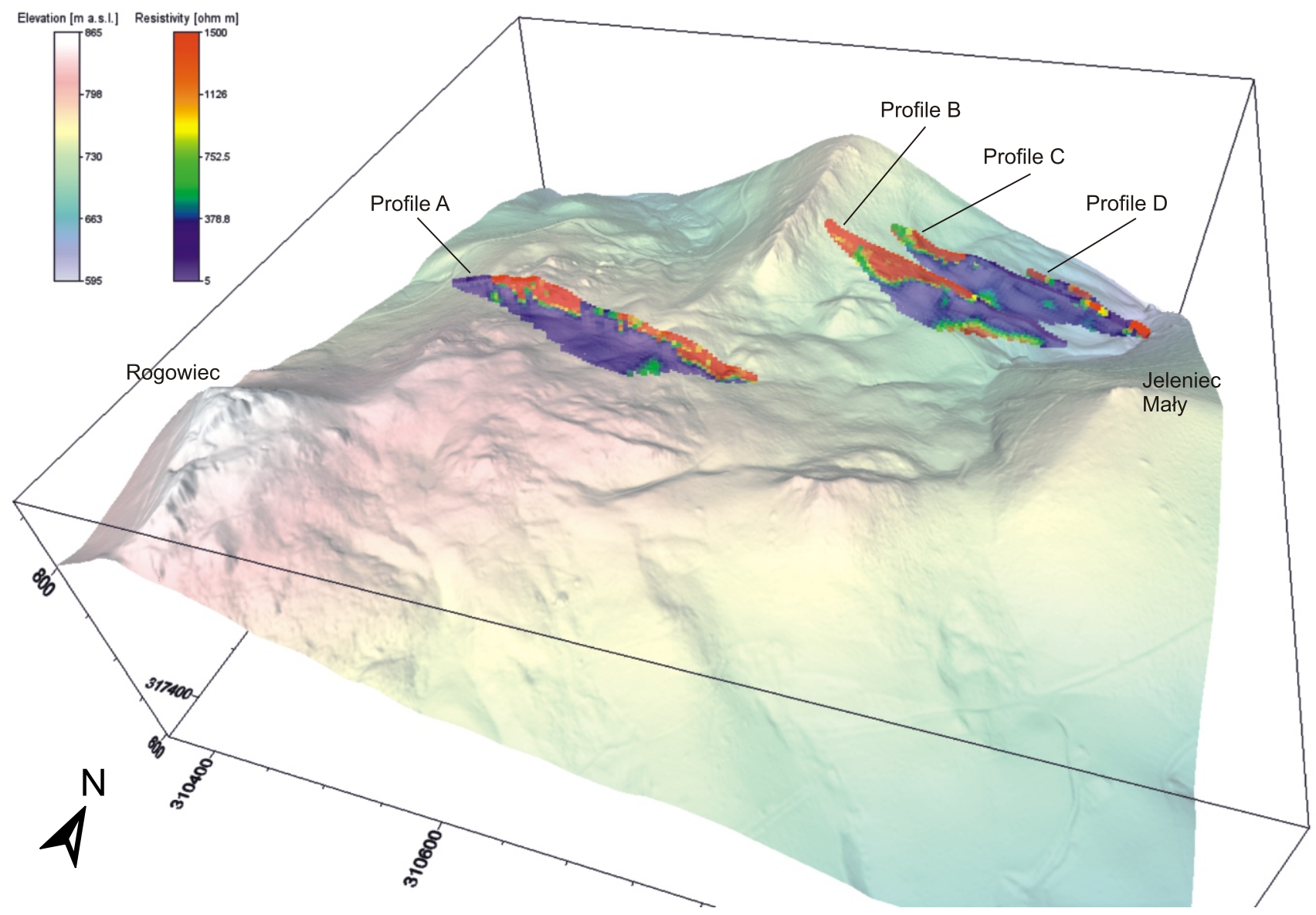

Fig. 11. Location of ERT profiles in relation to topography of the study area

of interpolation of point-specific data. The synthesis of measurement results is shown in Table 2.

Profile A, located across the axial part of the Rogowiec ridge, clearly shows that the bedrock is bipartite. The upper part, of variable depth between 10 and $30 \mathrm{~m}$, has distinctly higher resistivity than the lower part and the boundary between the two is moderately sharp. Since bedrock blocks present at the surface are invariably trachyandesites, the upper part is interpreted as volcanic caprock. The underlying rocks correspond to clastic sedimentary successions of significantly lower resistivity. The volcanic cap itself is further divided into individual blocks (zone "a", Fig. 12), separated by steeply dipping discontinuities, partially coincident with scarps at the surface bounding hills and hollows. These discontinuities tend to dip away from the axis of the ridge, especially in the eastern part. The central part of the profile, in the local hollow, shows very low resistivity values even close to the surface. This is likely to be the combined effect of high degree of fracturing and elevated water content, but alternatively, this section may be the place where sedimentary rock is close to the surface or original graben-like landforms are filled by debris. A few trachyandesite boulders are scattered at this particular location and the detailed geological map (Bossowski et al., 1994) indicates sedimentary rocks in the ridge position.

Profiles $B$ and $C$ are broadly parallel to each other and run perpendicularly to the trachyandesite ridge on its eastern slope, crossing uneven and moderately sloping terrain. Profile B starts close to the ridge top but terminates in the footslope hollow whereas profile $C$ reaches the footslope itself. In profile $B$ high-resistivity material occurs in the upper slope but it is underlain by substratum of much lower resistivity further down. The situation at the distance 50-160 m may be interpreted as the signature of downslope displacement of a rigid block of trachyandesites over sedimentary rocks ("b" in Fig. 12, profile B). In the lower slope, the near-surface layer of c. $15 \mathrm{~m}$ thickness, terminated in a steep toe, is evident. It may be interpreted as a thick colluvium, but involving bedrock different than that in the upper slope. This is consistent with surface observations indicating the presence of minor angular pieces of mudstone and sandstone littering the slope surface. The situation at profile $C$ is generally analogous, although the upper ("c") and lower ("d") layers of high and low resistivity, respectively, are thinner. Elevated resistivity of the convex toe reflects moisture content rather than subsurface lithology. No unequivocal evidence of a fault indicated on the 1:25,000 geological map (Bossowski et al., 1994) emerges from the ERT profiles although a low resistivity zone dipping to the west may be considered a manifestation of this structure.

Profile $D$ is diagonal to the toe zone and includes an enigmatic elongated swell in the very valley bottom ("e"). The geophysical signature of the toe itself is very similar to that revealed by profile $\mathrm{C}$, whereas the swell is distinctive by its higher resistivity. Since surface lithology is similar across the profile, dewatering towards the adjacent troughs is the most likely explanation. 


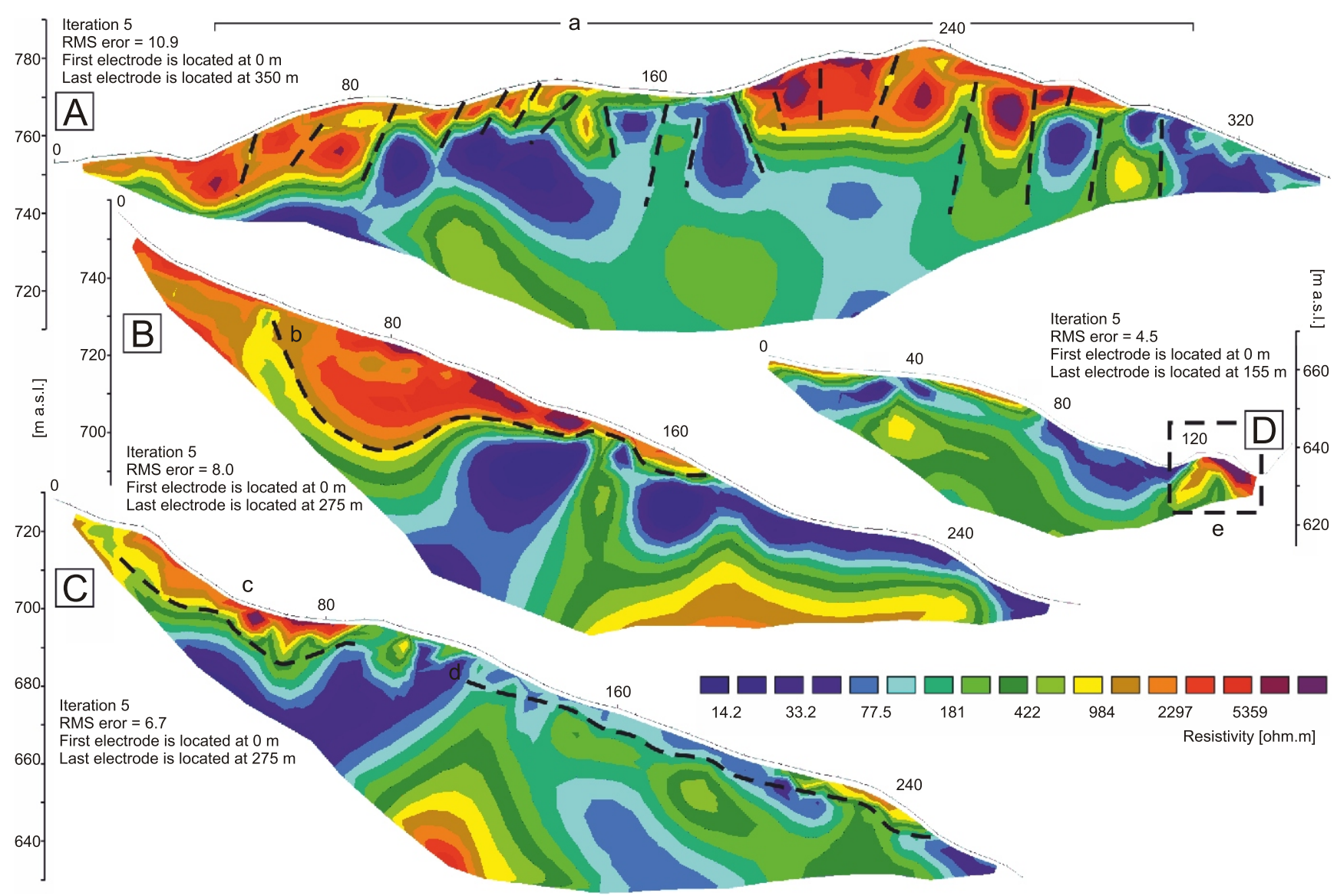

Fig. 12. ERT profiles across the broken divide zone (A) and the landslide terrain in the NE part of Rogowiec Landslide Complex For location of profiles see Figure 3

Summary of ERT measurements and inversion results

\begin{tabular}{|c|c|c|c|c|c|c|c|c|c|}
\hline \multirow[b]{2}{*}{ No. } & \multirow{2}{*}{$\begin{array}{l}\text { Profile } \\
\text { length } \\
\text { [m] }\end{array}$} & \multirow{2}{*}{$\begin{array}{l}\text { Electrode } \\
\text { spacing } \\
\text { [m] }\end{array}$} & \multirow{2}{*}{$\begin{array}{c}\text { Electrode } \\
\text { array }\end{array}$} & \multicolumn{4}{|c|}{ Apparent resistivity $[\Omega \mathrm{m}]$} & \multicolumn{2}{|c|}{ Inversion } \\
\hline & & & & $\stackrel{\rho}{\rho}$ median & $\begin{array}{c}\rho \\
\text { mean }\end{array}$ & $\stackrel{\rho}{S D}$ & $\stackrel{\rho}{\max }$ & Iteration & $\begin{array}{l}\text { RMS } \\
\text { error }\end{array}$ \\
\hline A & 350 & \multirow{4}{*}{5.0} & \multirow{4}{*}{$\begin{array}{c}\text { Wenner- } \\
\text { Schlumberger }\end{array}$} & 112.9 & 304.5 & 498.6 & 4841.7 & \multirow{4}{*}{5} & 10.9 \\
\hline$B$ & 275 & & & 165.4 & 520.9 & 729.2 & 4757.6 & & 8.0 \\
\hline C & 275 & & & 151.2 & 205.1 & 202.0 & 1754.4 & & 6.7 \\
\hline $\mathrm{D}$ & 255 & & & 136.5 & 235.1 & 451.6 & 4138.4 & & 4.5 \\
\hline
\end{tabular}

SD - standard deviation, RMS error - root-mean-square deviation (differences between value predicted by a model and the values measured)

\section{INTERPRETATION AND DISCUSSION}

\section{MASS MOVEMENT TYPOLOGY}

The combination of landform recognition and geomorphometric attributes, coupled with the results of ERT surveys, support previous views (Pulinowa, 1972; Bossowski et al., 1994; Synowiec, 2003, 2005; Migoń et al., 2014b) that Mt. Rogowiec and the adjacent ridges represent a complex landslide terrain From a genetic point of view one can distinguish at least seven separate units, each with its own style of deformation and bedrock displacement. They generally correspond with terrain classifications derived from DTM analysis and field geomorpho- logical mapping. However, the inner boundaries of the units cannot be traced with precision and should be considered as approximate (Fig. 13A).

The east-facing slopes of Mt. Rogowiec and the unnamed $776 \mathrm{~m}$ peak are interpreted as large, multiple slides (1 and 2; Fig. 13A). Their head scarps are $\mathrm{N}-\mathrm{S}$ oriented and follow one of the major vertical joint directions. In the landslide no. 2 secondary, less distinct detachment scarps are located to the south and particularly north of the head scarp. The series of discontinuous benches and steps in the upper slopes are considered as rigid blocks displaced downslope, with slight backward tilting indicative of minor rotation. In the middle and lower slopes these rigid blocks give way to rock masses which lost coherence during displacement and now form undulating topography of swells and 

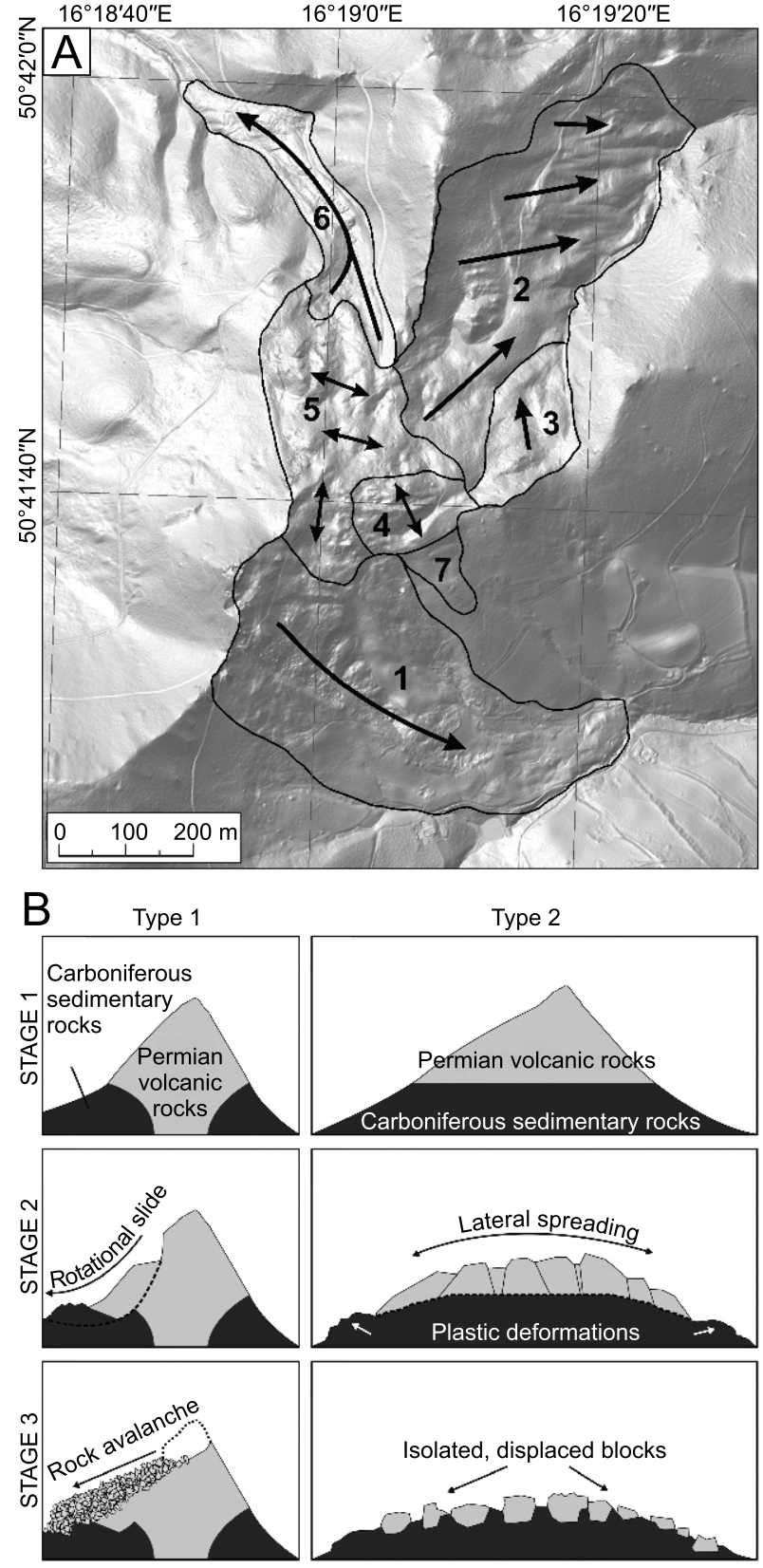

Fig. 13. Synthesis of results

A - division of the Rogowiec Landslide Complex into separate units, B - conceptual model of long-term slope deformation, depending on the rooting of volcanic caprock

troughs. The lithology of the surface materials as well as ERT results from landslide no. 2 indicate that morphological change corresponds with bedrock and rheological change. Rigid slid blocks in the upper slopes are built of volcanic rock, whereas the lower slopes are underlain by weaker sedimentary materials. The third landslide (no. 3), of minor dimensions, occurred on the $\mathrm{N}$-facing slope of the unnamed $792 \mathrm{~m}$ peak. However, its colluvial part merges with colluvium of landslide no. 2 and these two cannot be unequivocally separated from one another.

The morphology of the central part of the Rogowiec Landslide Complex is consistent with lateral spreading as the main type of deformation. However, two separate units may be distinguished (4 and 5; Fig. 13A). Part of the ridge between $826 \mathrm{~m}$ and $792 \mathrm{~m}$ peaks (no. 4) is still fairly compact and the most evident signs of deformation are parallel ridge-top trenches. Hence, an early stage of deformation may be inferred. By contrast, the remaining, much more extensive part (no. 5) displays a more advanced state of disintegration, with no in situ bedrock present. Locally, around the $786 \mathrm{~m}$ peak, ruiniform relief has developed, with massive trachyandesite compartments up to $30 \mathrm{~m}$ long and $10 \mathrm{~m}$ high. Topographic hollows are no longer orderly linear, but an irregular complex of elevations and depressions has developed instead.

Unit 6 begins at the northern margin of unit 5, in a distinct amphitheatre the floor of which is littered with massive trachyandesite boulders, surrounded by broken blocks of trachyandesite. Landform inventory further down the valley indicates flow type of movement channelled along a pre-existing fluvial valley. The flowing mass travelled for $>500 \mathrm{~m}$, carrying multiple blocks of trachyandesite on its top. The dimensions of these boulders and distinct levées on both sides show that the energy of flow must have been considerable.

Unit 7 is a rather indistinct bulge on the southern slope of the $\mathrm{W}-\mathrm{E}$ secondary ridge, next to the section of the ridge that is subject to lateral spreading in a $\mathrm{N}-\mathrm{S}$ direction. It is hypothesized that the bulge is the morphological manifestation of ongoing deformation within sedimentary rock under the load imposed by the volcanic cap.

\section{MODEL OF LANDSLIDE-DRIVEN LANDSCAPE EVOLUTION}

Two main factors responsible for the widespread gravitational deformation structures in the Mt. Rogowiec area are the spatial relationships between the volcanic and sedimentary rocks, as well as available relief. In fact, these two are closely related. Geomechanical and hydrogeological contrast between these two lithological groups is among the most significant in the Sudetes (Placek, 2011; Migoń and Placek, 2014) and surface observations show that exposures of volcanic rocks, whether of rhyolite or trachyandesite, show few signs of weathering, although may be heavily broken along multiple sets of fractures. By contrast, sedimentary rocks are much weaker and easily disintegrate, especially when moist. In the long term, these contrasts have given rise to elevation differences up to $400 \mathrm{~m}$ over short distances.

It has long been observed (Dathe et al., 1910; Dathe and Berg, 1926; Grocholski, 1972; Migoń et al., 2010, 2014b) that the contact zones between volcanic and sedimentary rocks are particularly prone to landsliding. The likely scenario involves long-term lithostatic load imposed by the volcanic caprock, progressive development of shear surfaces in the underlying sedimentary rocks, outward movement of soft sediments towards the slope surface, followed by disintegration of the rigid cap along pre-existing joints in the form of lateral spreading (see Gutiérrez et al., 2012). Deep-seated landslides no. 1, 2 and 3 are relevant examples, with the head scarp of landslide no. 1 illustrating varying distances of outward movement of detached trachyandesite blocks. Reasons why the landslides affected the east-facing slopes only, leaving the west-facing ones largely unaffected, are not clear. It is possible that the fault running east of Mt. Rogowiec, within the slopes, has additionally weakened the rock.

Landform inventory within the landslide no. 1 shows that the history of mass movement was even more complex. An unusual feature is the $200 \mathrm{~m}$ long block stream, superimposed on the bench-and-step topography in the upper slope and partially the hummocky relief in the middle slope. This landform, unparalleled in the Sudetes, is the product of large-scale rock slope 
collapse, probably iniitated by toppling of several closely spaced blocks detached from the head scarp followed by a rock avalanche. Rock mass deformation at Mt. Rogowiec appears ongoing, as suggested by archaeological investigations of the ruins of the medieval castle built at the end of the 13th century (Boguszewicz et al., 1991; Boguszewicz, 2010). The round castle tower, erected at the western tip of the narrow summit flat, broke into three separate parts which moved apart, apparently due to instability of the underlying bedrock. Later 14 th century attempts to restore the construction failed. Another evidence of rock mass disintegration is the presence of angular boulders in the former castle courtyard, derived from the rock wall above (actually, a section of the head scarp). However, one cannot exclude their release and fall during the siege of the castle in 1497.

Lateral spreading and complete disintegration of the volcanic cap inferred for the central part of the RLC requires different geological predisposition, i.e. the presence of deformable sedimentary beds across the whole width of the ridge. The ERT profile A demonstrates that this is likely the case and helps to interpret morphological relationships in terms of rock mass deformation. Comparison of areas no. 4 and 5 allows us to hypothesize the likely course of events. An initial stage involved deep-seated gravitational slope deformation (DSGSD), followed by opening of ridge-parallel trenches in the axial part. Lateral spreading ensued, leading to ridge collapses and filling of trenches and graben depressions. Over time, evidence of trenches largely disappeared and the area has become a subdued terrain with an apparently chaotic boulder cover. At some stage of development, the NW part of the area collapsed and moved into the pre-existing valley in a flow-type manner, involving both fine-grained sedimentary rocks as well boulders from the broken volcanic cap.

Thus, we propose that two different mechanisms of ridge disintegration have been in operation within the RLC, depending on the relationships between volcanic caprock and underlying sedimentary rocks (Fig. 13B). If the volcanic mass is rooted at depth by the original volcanic conduit (type 1), slope undermining occurs along the margins of the outcrop and landslides are confined to slopes, although head scarps may reach the crest lines. By contrast, if the cap is not rooted and sedimentary rocks crop out on both sides of the ridge, lateral spreading is favoured (type 2). Removal of disintegrated caprock may be accomplished by sliding or flow-type mechanisms, depending on the coherence of the material and local relief. The second mechanism appears rather common in volcanic tablelands, including the central part of the Bohemian Massif with many remnants of basaltic flows in topographically elevated positions (Pašek and Demek, 1969; Rybář, 2002), but in the Kamienne Mts. a layered structure of ridges is rather unusual and deep-seated rotational slides on steep slopes rather than lateral spreading prevail (Migoń et al., 2014b, 2016).

\section{BROADER CONTEXT}

Slope deformation structures recognized within the Rogowiec Landslide Complex have parallels elsewhere in the Kamienne Mts. Deep-seated slides with large displaced blocks, locally multiple, have been reported from several other localities, such as the Włostowa-Suchawa ridge, although none of these was initiated at the crest line (Migoń et al., 2010, 2016 Kacprzak et al., 2013). Elongated flowslide-derived valley fills, occasionally with dispersed boulder cover, are also known from a few places, for example to the south of the village of Sokołowsko (Migoń et al., 2010, 2014a). Likewise, evidence of incipient lateral spreading in the form of deep open clefts with specific air circulation (emergence of warm air in winter and cold air in summer), indicative of a system of interconnected underground voids, is available from the Lesista Wielka massif (Migoń et al., 2010). However, the juxtaposition of deformation structures of different types and their large extent makes the Rogowiec locality exceptional.

While deep-seated landslides within slopes truncating a massive caprock underlain by weak sedimentary successions are frequently reported (Brunsden and Jones, 1976; Busche, 1980; Hutchinson, 1995; Cruden and Varnes, 1996), there are fewer examples of gravitational spreading affecting entire watershed ridges. These are typically described from high-mountain settings, where slope debuttressing after deglaciation is considered as the main triggering factor (Jahn, 1964; Agliardi et al., 2001; Jarman, 2006; Ballantyne et al., 2013). Mesa landforms, characteristic of sedimentary tablelands, are another setting prone to lateral spreading (e.g. Zaruba and Mencl, 1982; Conti and Tosatti, 1996; Pasuto and Soldati, 1996; Vlčko, 2004), and there are examples of cleft opening, block gliding and toppling from the sandstone/mudstone tableland of the Stołowe Mts. (Middle Sudetes; Pašek and Pulinowa, 1976; Migon and Kasprzak, 2015) and the northern part of the Bohemian Cretaceous Basin in the Czech Republic (Forczek, 2008). However, most studies focus on early phases of lateral spreading, whereas in the RLC we are able to observe a wide range of stages of their long-term evolution, including a very advanced phase of this process, at which restoration of original caprock topography is no longer possible.

The RLC example demonstrates that in specific circumstances (structural predisposition, high available relief, little surface drainage) gravitational slope deformation mechanisms may be the main components of landscape evolution even in low-altitude mountain settings, far outweighing the role of fluvial processes. Their role is not local, confined to specific slope sections, but they are capable of remodelling entire hillslopes, from crest lines to valley bottoms. Thus, the RLC is a good example of "landslide geomorphology" (sensu Crozier, 2010) and landslide-controlled denudation systems.

\section{CONCLUSIONS}

The Rogowiec Landslide Complex (RLC) is among the largest in the Sudetes and the most diverse. It covers $>40$ ha and extends from the axial part of the Rogowiec ridge towards valley floors on both sides, but particularly to the east and north-east. The RLC consists of a number of distinctive units the morphological signatures of which suggest different types of displacement, related to geological conditions and the variable degree of disintegration of the slid mass. Deep-seated landslides have been generated along the shearing zones rooted in the weaker sedimentary rocks. However, they are geomorphologically complex, reflecting the presence of displaced rigid blocks of trachyandesite in the upper slope sections and widespread deformation of underlying sedimentary successions in the lower slope. Wavy and hummocky topography typifies the distal parts of the landslides. The pattern of deformation is different in the central part of the RLC, where the ridge collapsed giving rise to irregular relief, with elevations crowned by jointed trachyandesite blocks or chaotically spread boulders, interspersed with troughs and hollows. This peculiar type of morphology, unknown anywhere else in the Sudetes, is interpreted as the advanced stage of lateral spreading that involved rigid volcanic cap overlying soft sedimentary deposits. The diversity of mass movements within the RLC is supplemented by flows 
and rock wall collapses, the latter resulting in spectacular block streams. In terms of internal diversity, the RLC is unique in the area and provides an excellent example of a highly complex landslide terrain.

This study shows the value of using various complementary research methods in the recognition of apparently relict landslides and related phenomena. Whilst LiDAR DTM proved extremely useful in terrain characterization, delimitation of slopes affected by deformation processes, and preliminary division of the area into smaller units, field geomorphological mapping was necessary to constrain the picture. In particular, minor landforms such as boulder covers could have been unequivocally identified only through field mapping. Fracture measurements helped to relate geomorphic features to structural control and predisposition. Finally, electrical resistivity tomography revealed geological conditions in the subsurface, especially the spatial relationship between volcanic caprock and sedimentary successions within the landslide-affected slopes, and confirmed the diversity of slope deformation structures in the Rogowiec area.
Although several issues are not yet been resolved, particularly the timescale of slope deformation processes, the mechanics of flows into the valleys, and the current state of activity, the Rogowiec Landslide Complex is currently the most comprehensively analysed landslide terrain in the Sudetes.

Acknowledgements. The research reported in this paper was supported by statutory funds available in the Institute of Geography and Regional Development, University of Wrocław. The authors express their thanks to M. Crozier and A. Dykes whose comments during visits to the study area helped us to understand the complex pattern of slope deformation. F. Gutiérrez and an anonymous reviewer are thanked for providing helpful reviews of the early version of the paper. LiDAR data used for this study, have been purchased and used with academic license DIO.DFT.DSI.7211.1619.2015 PL N, according to the Polish law regulations in the administration of Central Bureau of Geodesy and Cartography.

\section{REFERENCES}

Aichler, J., Pecina, V., 1998. Documentation of landslides connected with the floods in 1977 in the Jeseníky area (in Czech with English summary). Geologické výzkumy na Moravě a ve Slezsku w roce 1997: 94-96. Český geologický Ústav, Brno,

Agliardi, F., Crosta, G., Zanchi, A., 2001. Structural constraints on deep-seated slope deformation kinematics. Engineering Geology, 59: 83-102.

Allmendinger, R.W., 2013. Stereonet Help - the user's manual for Stereonet 8 .

Allmendinger, R.W., Cardozo, N.C., Fisher, D., 2012. Structural Geology Algorithms: Vectors and Tensors. Cambridge University Press, Cambridge.

Awdankiewicz, M., 1999. Volcanism in a late Variscan intramontane trough: Carboniferous and Permian volcanic centers of the Intra-Sudetic Basin, SW Poland. Geologia Sudetica, 32: $13-47$

Ballantyne, C.K., Wilson, P., Schnabel, C., Xu, S., 2013. Late glacial rock slope failures in north-west Ireland: age, causes and implications. Journal of Quaternary Sciences, 28: 789-802.

Boguszewicz, A., 2010. Corona Silesiae. Zamki Piastów furstenberskich na południowym pograniczu księstwa jaworskiego, świdnickiego i ziębickiego do połowy XIV wieku (in Polish). Wydział Nauk Historycznych i Pedagogicznych Uniwersytetu Wrocławskiego, Katedra Etnologii i Antropologii Kulturowej. Wrocław.

Boguszewicz, A., Dwojak, A., Ziółkowski, W., 1991. Zamek Rogowiec. Wyniki prac archeologiczno-architektonicznych w 1989 r. (in Polish). Śląskie Sprawozdania Archeologiczne, 32 263-299.

Bossowski, A., Ihnatowicz, A., 1994. Palaeogeography of the uppermost Carboniferous and lowermost Permian deposits in NE part of the Intra-Sudetic Depression. Geological Quarterly, 38 (4): 709-726.

Bossowski, A., Cymerman, Z., Grocholski, A., Ihnatowicz, A., 1994. Szczegółowa Mapa Geologiczna Sudetów 1:25 000, arkusz Jedlina Zdrój (in Polish). Wyd. Geol., Warszawa.

Brunsden, D., Jones, D.K.C, 1976. The evolution of landslide slopes in Dorset. Philosophical Transactions of the Royal Society of London, A283: 605-631.

Busche, D., 1980. On the origin of the Msak Mallat and Hamadat Manghini Escarpment. In: The Geology of Libya (eds. M.J. Salem and M.T. Busrewil): 837-848. Academic Press, London.
Cardozo, N., Allmendinger, R.W., 2013. Spherical projections with OSXStereonet. Computers \& Geosciences, 51: 193-205.

Carpentier, S., Konz, M., Fischer, R., Anagnostopoulos, G., Meusburger, K., Schoeck, K., 2012. Geophysical imaging of shallow subsurface topography and its implication for shallow landslide susceptibility in the Urseren Valley, Switzerland. Journal of Applied Geophysics, 83: 46-56.

Conti, S., Tosatti, G., 1996. Tectonic vs gravitational processes affecting Ligurian and Epiligurian units in the Marecchia valley (northern Apennines). Memorie di Scienze Geologiche, 48: 107-142.

Crozier, M.J., 2010. Landslide geomorphology: An argument for recognition, with examples from New Zealand. Geomorphology, 90: 3-15.

Cruden, D.M., Varnes, D.J., 1996. Landslide types and processes. In: Landslides: Investigation and Mitigation (eds. A.K. Turner and R.L. Schuster), 247: 36-75. Transportation Research Board, National Academy of Sciences, Washington D.C., Special Report.

Czerwiński, J., Żurawek, R., 1999. The geomorphological effects of heavy rainfalls and flooding in the Polish Sudetes in July 1997. Studia Geomorphologica Carpatho-Balcanica, 33: 27-43.

Dathe, E., Berg, G. 1926. Erläuterungen zur Geologischen Karte von Preußen und benachbarten deutschen Ländern. Lieferung 145. Blatt Waldenburg i. Schl. Berlin (2. Aufl.).

Dathe, E., Zimmermann, E., Berg, G., 1910. Erläuterungen zur Geologischen Karte von Preußen und benachbarten Bundesstaaten. Lieferung 145. Blatt Friedland i. Schl. Berlin.

Fisher, N.I., 1995. Statistical Analysis of Circular Data. Cambridge University Press, Cambridge.

Forczek, I., 2008. Destruction of marginal parts of sandstone plateaus in the Protected Landscape Area Bohemian Paradise. Acta Geodynamica et Geomaterialia, 5: 267-274.

Grocholski, A., 1972. Ślady osuwisk na stokach Lesistej Wielkiej w Górach Kamiennych (in Polish). Polskie Towarzystwo Miłośników Nauk o Ziemi, Koło Górnicze w Gorcach, Biuletyn Informacyjny, 11: 9-14.

Gutiérrez, F., Linares, R., Roqué, C., Zarroca, M., Rosell, J., Galve, J.P., Carbonell, D., 2012. Investigating gravitational grabens related to lateral spreading and evaporite dissolution subsidente by means of detailed mapping, trenching, and electrical resistivity tomography (Spanish Pyrenees). Lithosphere, 4: 331-353. 
Hutchinson, J.N., 1995. Deep-seated mass movements on slopes. Memorie della Societa Geologica Italiana, 50: 147-164.

Jahn, A., 1964. Slopes morphological features resulting from gravitation. Zeitschrift für Geomorphologie, Suppl.-Bd., 5: 59-72.

Jarman, D., 2006. Large rock slope failures in the Highlands of Scotland: characterisation, causes and spatial distribution. Engineering Geology, 83: 161-182.

Kacprzak, A., Migoń, P., Musielok, Ł., 2013. Using soils as indicators of past slope instability in forested terrain, Kamienne Mts, SW Poland. Geomorphology, 194: 65-75.

Kneisel, C., 2006. Assessment of subsurface lithology in mountain environments using 2D resistivity imaging. Geomorphology, 80: 32-44.

Loke, M.H., 2000. Electrical imaging syrveys for environmental and engineering studies. A practical guide to 2-D and 3-D surveys, Geotomo. Malaysia.

Loke, M.H., Chambers, J.E., Rucker, D.F., Kuras, O., Wilkinson, P.B., 2013. Recent developments in the direct-current geoelectrical imaging method. Journal of Applied Geophysics, 95: 135-156.

Migoń, P., Kasprzak, M., 2011. Morfologiczny zapis ruchów masowych na progach morfologicznych Gór Stołowych w świetle numerycznego modelu wysokości o dużej rozdzielczości (in Polish). Przyroda Sudetów, 14: 115-124.

Migoń, P., Kasprzak, M., 2015. LiDAR DEM-based analysis of geomorphology of the Szczeliniec Wielki mesa in Poland's Stołowe Mountains (in Polish with English summary). Przegląd Geograficzny, 87: 27-52.

Migoń, P., Kasprzak, M., 2016. Pathways of geomorphic evolution of sandstone escarpments in the Góry Stołowe tableland (SW Poland) - insights from LiDAR-based high-resolution DEM. Geomorphology, 260: 51-63.

Migoń, P., Placek, A., 2014. Lithological and structural control on the relief of the Sudetes (in Polish with English summary). Przegląd Geologiczny, 62: 36-43.

Migoń, P., Pánek, T., Malik, I., Hrádecký, J., Owczarek, P., Šilhán, K., 2010. Complex landslide terrain in the Kamienne Mountains, Middle Sudetes, SW Poland. Geomorphology, 124: 200-214.

Migoń, P., Kacprzak, A., Malik, I., Kasprzak, M., Owczarek, P., Wistuba, M., Pánek, T., 2014a. Geomorphological, pedologica and dendrochronological signatures of a relict landslide terrain, Mt Garbatka (Kamienne Mts), SW Poland. Geomorphology, 219: 213-231.

Migoń, P., Jancewicz, K., Kasprzak, M., 2014b. The extent of landslide-affected areas in the Kamienne Mountains (Middle Sudetes) - a comparison of geological maps and a LiDAR based digital elevation model (in Polish with English summary). Przegląd Geologiczny, 62: 463-471.

Migoń, P., Różycka, M., Michniewicz, A., Kasprzak, M., 2015 Identyfikacja form osuwiskowych na podstawie danych LiDAR wybrane przykłady z Sudetów Środkowych i Zachodnich (in Polish). In: Ogólnopolska Konferencja Osuwisko, 19-22 maja 2015, Wieliczka: 107-108. Państwowy Instytut Geologiczny Państwowy Instytut Badawczy, Warszawa.

Migoń, P., Duszyński, F., Jancewicz, K., Różycka, M., Kasprzak, M., 2016. Large-scale slope remodelling by landslides geomorphic diversity and geological controls, Kamienne Mts, Central Europe. Geomorphology, DOI: 10.1016/j.geomorph.2016.09.037

Olaya, V., Conrad, O., 2008. Geomorphometry in SAGA. In: Geomorphometry: Concepts, Software, Applications. Developments in Soil Science (eds. T. Hengl and H.I. Reuter), 33: 293-308. Elsevier.

Pánek, T., Hradecký, J., Šilhán, K., 2008. Application of electrical resistivity tomography (ERT) in the study of various types of slope deformations in anisotropic bedrock: case studies from the Flysch Carpathians. Studia Geomorphologica Carpatho-Balcanica, 42: 57-73.

Pánek, T., Tábořík, P., Klimeš, J., Komárková, V., Hradecký, J., Š astný, M., 2011. Deep-seated gravitational slope deforma- tions in the highest parts of the Czech Flysch Carpathians: evolutionary model based on kinematic analysis, electrical imaging and trenching. Geomorphology, 129: 92-112.

Pašek, J., Demek, J., 1969. Mass movements near the community of Stadice in north western Bohemia. Studia Geographica (Brno), 3: 1-17.

Pašek, J., Pulinowa, M.Z., 1976. Block movements of Cretaceous sandstones in the Stolowe Gory Mts., Poland. Bulletin of the International Association of Engineering Geology, 13: 79-82.

Pasuto, A., Soldati, M., 1996. Rock spreading. In: Landslide Recognition (eds. R. Dikau, D. Brunsden, L. Schrott and M.-L. Ibsen): 122-136. Wiley, Chichester.

Perrone, A., Lapenna, V., Piscitelli, S., 2014. Electrical resistivity tomography technique for landslide investigation: a review. Earth-Science Reviews, 135: 65-82.

Pilous, V., 1977. Strukturní mury v Krkonoších - III. část. Opera Corcontica, 14: 7-94.

Placek, A., 2011. Rzeźba strukturalna Sudetów w świetle wyników pomiarów wytrzymałości skał i analiz numerycznego modelu wysokości (in Polish). Rozprawy Naukowe Instytutu Geografii i Rozwoju Regionalnego Uniwersytetu Wrocławskiego, 16: $1-190$.

Pulinowa, M.Z., 1972. Landslide processes in man-made and natural environment. Dokumentacja Geograficzna IG PAN, 4.

Reynolds, J.M., 2011. An Introduction to Applied and Environmental Geophysics ( $2^{\text {nd }}$ Edition). Wiley, Chichester.

Różycka, M., Michniewicz, A., Migoń, P., Kasprzak, M., 2015. Identification and morphometric properties of landslides in the Bystrzyckie Mountains (Sudetes, SW Poland) based on data derived from airborne LiDAR. In: Geomorphometry for Geosciences (eds. J. Jasiewicz, Z. Zwoliński, H. Mitasova and T. Hengl): 247-250. Adam Mickiewicz University in Poznań - Institute of Geoecology and Geoinformation, International Society for Geomorphometry, Poznań.

Rybář, J., 2002. Regional types of deep-seated slope failures in the areas of Tertiary volcanics in the Bohemian Massif. In: Landslides (eds. J. Rybář, J. Stemberk and G. Wagner): 299-303. Swets \& Zeitlinger, Lisse.

Samouëlian, A., Cousin, I., Tabbagh, A., Bruand, A., Richard, G., 2005. Electrical resistivity survey in soil science: a review. Soil and Tillage Research, 83: 173-193.

Schrott, L., Sass, O., 2008. Application of field geophysics in geomorphology: Advances and limitations exemplified by case studies. Geomorphology, 93: 55-73.

Sithole, G., Vosselman, G., 2004. Experimental comparison of filter algorithms for bare-Earth extraction from airborne laser scanning point clouds. ISPRS Journal of Photogrammetry and Remote Sensing, 59: 85-101.

Sørensen, R., Zinko, U., Seibert, J., 2006. On the calculation of the topographic wetness index: evaluation of different methods based on field observations. Hydrology and Earth System Sciences, 10: 101-112.

Synowiec, G., 2003. Landslides in the Kamienne Mts, Sudetes (SW Poland) (in Polish with English summary). Przegląd Geologiczny, 51: 59-65.

Synowiec, G., 2005. Formy i procesy osuwiskowe w Górach Kamiennych (in Polish). Unpublished PhD thesis, Instytut Geografii i Rozwoju Regionalnego, Uniwersytet Wrocławski.

VIčko, J., 2004. Extremely slow slope movements influencing the stability of Spis Castle, UNESCO site. Landslides, 1: 67-71.

Wężyk, P., ed., 2014. Podręcznik dla uczestników szkoleń z wykorzystania produktów LiDAR (in Polish). Informatyczny System Osłony Kraju przed nadzwyczajnymi zagrożeniami, Główny Urząd Geodezji i Kartografii, Warszawa.

Zaruba, Q., Mencl, V., 1982. Landslides and Their Control. Elsevier, Amsterdam.

Żurawek, R., 1999. Zmiany erozyjne w dolinach rzek Sudetów Kłodzkich wywołane powodziami w lipcu 1997 r. oraz w lipcu 1998 r. (in Polish). Problemy Zagospodarowania Ziem Górskich, 45: 43-61. 